\title{
Financing Green Urban Infrastructure
}
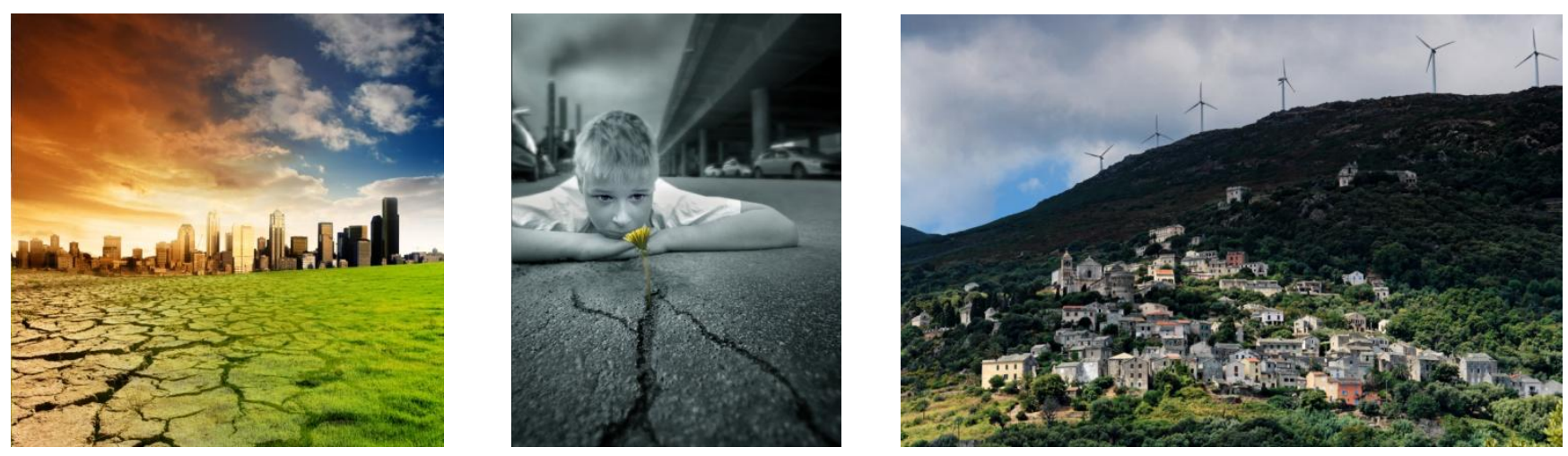

Merk, O., Saussier, S., Staropoli, C., Slack, E., Kim, J-H (2012), "Financing Green Urban Infrastructure", OECD Regional Development Working Papers 2012/10, OECD

Publishing; http://dc.doi.org/10.1787/5k92p0c6j6r0-en

\section{OECD Regional Development Working Papers 2012/10}

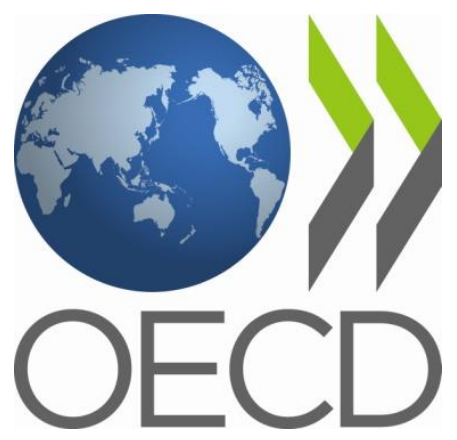

LA FABRIQUE

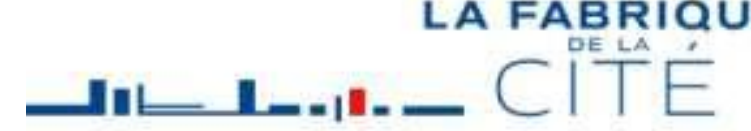




\begin{abstract}
This paper presents an overview of practices and challenges related to financing green sustainable cities. Cities are essential actors in stimulating green infrastructure; and urban finance is one of the promising ways in which this can be achieved. Cities are key investors in infrastructure with green potential, such as buildings, transport, water and waste. Their main revenue sources, such as property taxes, transport fees and other charges, are based on these same sectors; cities thus have great potential to "green" their financial instruments. At the same time, increased public constraints call for a mobilisation of new sources of finance and partnerships with the private sector. This working paper analyses several of these sources: public-private partnerships, tax-increment financing, development charges, value-capture taxes, loans, bonds and carbon finance. The challenge in mobilising these instruments is to design them in a green way, while building capacity to engage in real co-operative and flexible arrangements with the private sector.
\end{abstract}

Keywords: infrastructure finance, urban infrastructure, urban development, urban finance, private finance, public-private partnerships, green growth 


\section{FOREWORD}

This paper was produced in co-operation with la Fabrique de la Cité/ The City Factory (VINCI) and was approved by the 14th session of the OECD Working Party on Urban Areas, 6 December 2011.

The report has been produced and co-ordinated by Olaf Merk, under responsibility of Lamia Kamal-Chaoui (Head of OECD Urban Unit) and Joaquim Oliveira Martins (Head of OECD Regional Development Policy Division). The report has benefitted from contributions from Remi Dorval (La Fabrique de la Cité), Stéphane Saussier (IAE - Sorbonne Business School), Carine Staropoli (University Paris I Sorbonne), Enid Slack (Munk School of Global Affairs, University of Toronto), Jay-Hyung Kim (Public and Private Infrastructure Investment Management Center, Korea Development Institute), and Adeline Pelletier (Consultant, OECD). Valuable comments during the drafting of the report were provided by Chris Kennedy, Jan Corfee-Morlot, Heidi Smith and Tadashi Matsumoto (OECD). Caitlin Connelly edited the report.

The authors are grateful to Mr. Remi Dorval, President of La Fabrique de la Cité for his support and interest in OECD activities on Green Cities.

Please address further enquiries about this work to Olaf Merk (olaf.merk@ oecd.org) 


\section{TABLE OF CONTENTS}

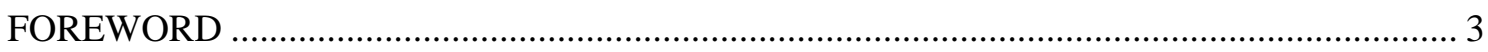

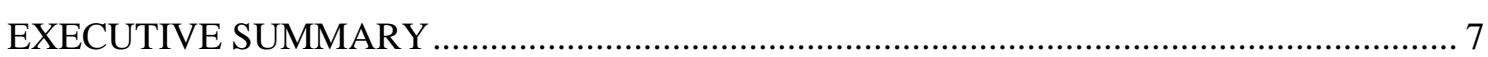

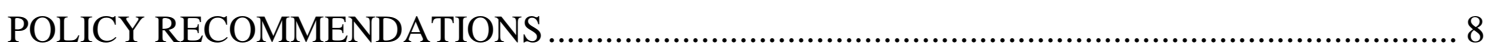

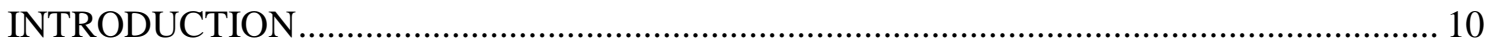

1. URBAN FINANCE AND GREEN INFRASTRUCTURE ................................................. 12

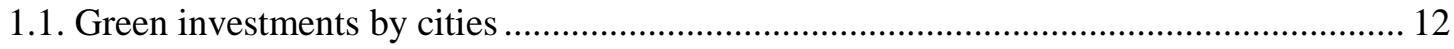

1.2. Revenues and green cities; getting the incentives right .................................................. 20

1.3. Revenue and green cities: the case of the property tax ....................................................... 25

2. PRIVATE FINANCE AND GREEN URBAN INFRASTRUCTURE..................................... 28

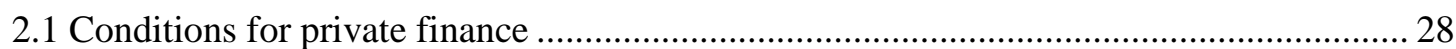

2.2 Involving the private sector through Public-Private Partnerships (PPPs)......................... 29

2.3 Stimulating private investment: the case of Tax Increment Financing (TIF) ..................... 36

2.4 Making the developer pay: development charges and value capture................................. 38

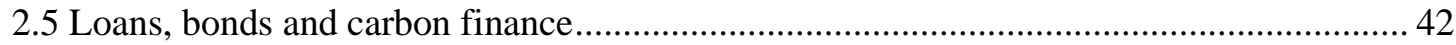

ANNEX 1: THE PROMISES AND PITFALLS OF PUBLIC-PRIVATE PARTNERSHIPS .. 45

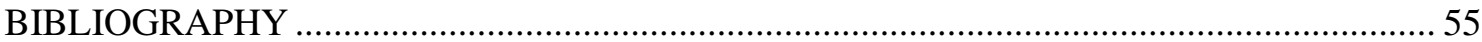

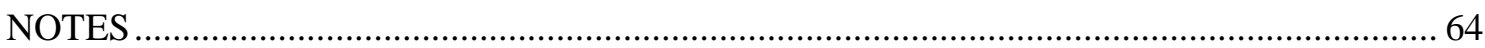




\section{LIST OF ABBREVIATIONS}

\begin{tabular}{|c|c|}
\hline $\mathrm{ADB}$ & Asian Development Bank \\
\hline $\mathrm{BAB}$ & Build America Bonds \\
\hline $\mathrm{BC}$ & British Columbia \\
\hline BRIICS & Brazil, Russia, India, Indonesia, China and South Africa \\
\hline CEPAC & $\begin{array}{l}\text { Special Additional Potential Construction Certificates (Certificados de Potencial } \\
\text { Adicional de Construção) }\end{array}$ \\
\hline CDM & Clean Development Mechanism \\
\hline CREB & Clean Energy Renewable Bonds \\
\hline BID & business improvement district \\
\hline EIB & European Investment Bank \\
\hline EUR & euro \\
\hline FAR & floor area ratio \\
\hline FSI & floor space index \\
\hline GDP & gross domestic product \\
\hline GHG & greenhouse gas \\
\hline GTA & Greater Toronto Area \\
\hline IEA & International Energy Agency \\
\hline JI & Joint Implementation \\
\hline ICGF & infrastructure credit guarantee fund \\
\hline LCOE & levelised cost of energy \\
\hline MSA & Metropolitan Statistical Areas \\
\hline MWh & megawatt \\
\hline NAO & UK National Audit Office \\
\hline OECD & Organisation for Economic Co-operation and Development \\
\hline PACE & Property Assessed Clean Energy Bonds \\
\hline PPP & public-private partnership \\
\hline
\end{tabular}


QUECB Qualified Energy Conservation Bonds

TIF tax increment financing

TMAP Transport Management and Accessibility Plan

UK United Kingdom

UNFCCC United Nations Framework Convention on Climate Change

US United States

USD United States dollars

WEF World Economic Forum 


\section{EXECUTIVE SUMMARY}

Cities play a critical role in planning and investing in urban infrastructure. In many cases, local governments have authority over the selection of infrastructure projects made at the municipal level. Therefore, they exercise influence over the nature of infrastructure renewal and expansion, and have the ability to promote greener and more sustainable urban centres. Their leadership role extends to the kinds of investment mechanism selected to finance, for example, improvements in the transportation, building, waste and water and, to a lesser extent, energy sector. Because cities have revenue sources that are tied to many aspects of these sectors, their design can stimulate or dissuade the development of greener and more sustainable cities.

The greening of municipal financial instruments, such as congestion charges, variable parking fees, toll lanes and split-rate property taxes, is an important first step toward achieving greener urban infrastructure. Public sector financing, however, may not be sufficient to stimulate a paradigm shift. Therefore, the second critical step is to mobilise private sector investments to fill funding gaps for many urban green infrastructure projects. There are certain conditions that need to be put in place in order to attract and capture private sector investments. The three main conditions are (1) markets for green urban investment projects, (2) good return on investment and (3) limited risk. Cities and countries differ with respect to these conditions; as such, some of these instruments could be more appropriate for cities in industrialised and medium income countries than lower income developing countries, for which grants, loans and other development finance instruments could be more relevant.

There are several existing financial instruments that cities have applied in order to attract private finance for urban green infrastructure:

- Private sector involvement in urban green infrastructure can take the form of public-private partnerships (PPPs), in which the long-term risk is transferred to the private sector.

- Through an alternative instrument, tax increment financing, future tax revenues are used to attract private finance.

- Real estate developers may also pay for the infrastructure that is needed to connect their new development to existing infrastructure in the form of development charges (impact fees) and value capture (taxes that capture the value increases of real estate due to new infrastructure development nearby).

- Finally, loans, bonds and carbon finance are instruments used to attract private finance in well-functioning capital markets. 


\section{POLICY RECOMMENDATIONS ${ }^{1}$}

\section{Policy alignment across levels of government}

1. National policies are key. The greener the national framework, the easier it will be to address city-specific challenges and to ensure coherence and consistency between national and local policies. The national framework is particularly important with respect to pricing signals for non-localised environmental externalities, such as GHG emissions. Moreover, in many countries, reform of urban revenue sources requires central government action.

2. Remove barriers to local government action. While national governments may face challenges to immediately implementing holistic reforms, they can start by eliminating current regulations that impair the potential for local governments to act.

3. A holistic approach is necessary. Efforts to green urban revenue sources may have undesirable distributional consequences. These concerns should be addressed in the context of the entire tax and benefit system, rather than trying to ensure that each individual policy measure serves both environmental and equity objectives.

4. Keep the policy package simple. While the design of specific instruments will in many cases need to be quite sophisticated, it is important to keep the overall policy package as simple as possible. An overly complex system of environmental taxes, charges and fees makes impact assessment harder and raises the risk of unintended interaction effects or perverse incentives.

\section{Making existing revenue sources greener}

5. The overriding aim is to internalise externalities. To the extent possible, taxes, charges and fees should be designed to confront agents with the full marginal social cost of actions affecting the environment. At a minimum, this means eliminating the anti-green bias of some existing local tax provisions and the perverse incentives created by many environmentally harmful subsidies.

6. Road-pricing policies can help reduce traffic and pollution. Road-pricing policies like congestion charges are likely to be most effective at reducing traffic and emissions when differentiated according to the level of congestion, peak hours or both. Linking pricing structures to vehicle type as well may strengthen incentives to switch to greener forms of transport.

7. Transport-related revenue sources require coherent planning. The use of congestion charges to achieve green objectives will be more effective and less costly to users when alternative mobility solutions are available; governments might consider earmarking such revenues to finance public transportation.

8. Fees for water and waste services should be more responsive to actual resource use. Fees and prices should be used to signal the scarcity of the resources being consumed, as well as covering the costs of infrastructure investment and service provision.

9. Where appropriate, intergovernmental grants should take into account environmental objectives. This will help compensate cities for the opportunity costs of green behaviour 
(e.g., the loss of development charges if an area is designated as a public park). Specific or matching grants can compensate local governments for the spillovers generated by green policies that incur localised costs but generate broad benefits.

\section{Tapping new sources of finance}

10. Carbon finance should be more accessible to cities. Cities and central governments can work together to make better use of carbon-offsetting programmes (e.g., the Clean Development Mechanism and Joint Implementation) and to ensure that these (and other) resources may come directly to cities. One of the conditions of carbon finance should be use of a harmonised emission inventory for cities.

11. Infrastructure needs related to new development should be internalised in the financing of development projects. The costs of sprawl, for example, may be recovered from developers through development charges or other financial contributions. In a similar fashion, new developments should also, where appropriate, incorporate the cost of investment in alternative water sources.

12. National-local co-operation is essential to developing access to new forms of green finance. There are a number of potential instruments for tapping private finance in support of urban greening and aligning private investment with policy priorities. These include private-public partnerships, green bonds and green infrastructure banks. However, they each raise potential problems of insufficient size, moral hazard and opportunism. Cities thus need to co-operate with one another and with central governments to build capacity and ensure that they possess the requisite financial, technical and legal expertise, as well as sufficient bargaining power when negotiating private-sector financing. 


\section{INTRODUCTION}

Cities are central to greening urban infrastructure. They occupy $2 \%$ of the world's landmass but are responsible for more than two-thirds of global energy use and greenhouse gas emissions (IEA, 2008). A majority of the world's population lives in cities; this majority is expected to reach two-thirds by 2050 . Within the next decade, there will be nearly 500 cities of more than a million people, including several "megacities" with population exceeding 20 million (OECD, 2011). Furthermore, the decentralisation of government in many countries has put most of the operational decision making in the hands of the cities rather than at the national level. Thus, cities are key engines for economic growth but also a major contributor to global warming and environmental problems.

The transition to green cities is an essential process that will require overcoming many challenges, particularly with regard to technology, governance and financing. The deployment of technology and capacity compatible with the goals calls for investments that are, in certain respects, unusual in terms of three key properties:

Size: Whether the aim is to improve the energy performance of the built environment, organise carbon-free urban mobility, adapt existing networks or ensure waste collection and treatment, the entire existing infrastructure stock will have to be renovated, modified and modernised. Greening cities therefore concerns not only new infrastructure relating to the development of cities, but also the transformation of existing infrastructure. In addition, efforts will need to be made to finance the necessary technological innovations. Cities will require high levels of investment in the years to come in order to finance these changes - investment levels that will exceed business-as-usual infrastructure maintenance.

Concentration over time: The benefits of greening urban infrastructure extend beyond local and national borders to issues, such as climate change, being fought at the international level. Greening cities helps to mitigate and adapt to the pressing challenges presented by climate change. The additional investments required will therefore be concentrated over a relatively short period of time, making it harder to resolve the issue of financing these investments.

Nature: An important outcome (or result) of green initiatives is their positive long-term environmental impact on cities. The corresponding conditions for investment require the development of innovative financing mechanisms that are resilient to the three main characteristics of green projects.

- They generate positive externalities and are often justified through a collective social benefit that cannot be readily quantified in economic terms. Infrastructure aimed at reducing greenhouse gases exemplifies this characteristic.

- They produce effects over the very long term, which makes it hard to advance conventional economic arguments regarding the financing of investments. 
- They carry a high degree of risk, especially related to uncertainty of the regulatory and economic environment (energy prices, cost of carbon dioxide, etc.).

Securing financing for green initiatives requires innovative solutions that combine both public and private funds because public funds alone are inadequate in the current fiscal environment. Leveraging global investment through the use of private financing makes sense and is possible, provided that reasonable conditions of profitability, risk and timeframes can be ensured. Numerous studies, conducted to identify strategies to secure sufficient financing, led to the following findings:

- There could be an array of investments for green cities; each type of investment must generate its own business model that can provide a basis for a financing method.

- The identification and valuation of externalities through public policy informs the investment mobilisation and selection process resulting in better matches between financing choice and project.

- Joint public-private approaches work when they are based on a precise analysis of the value created by the investment, its positioning (public or private sphere), its long-term nature and the capacity of different players to understand it. Risk analysis and effective sharing of this risk must also be taken into consideration.

- The decision-making environment is rapidly evolving; this creates uncertainty, but also opportunity for new sources of investment related to behavioural change (i.e. socially responsible investments). 


\section{URBAN FINANCE AND GREEN INFRASTRUCTURE}

Urban finance has a potentially large role to play in greening infrastructure. Cities invest in both green infrastructure (i.e. infrastructure developed to serve an environmentally beneficial function, such as environmental protection) and "greenable" infrastructure (i.e. existing infrastructure, like transportation, that can be improved to reduce its environmental impact). Moreover, cities have revenue sources that are tied to many of these infrastructure-related sectors, such as building and transport. The design of these revenue sources, especially property taxation, can stimulate or discourage green cities. The following sections - addressing cities' "greenable" infrastructure investments, green urban revenue sources and financial incentives for greening the urban property tax - will elaborate on this concept.

\section{1. "Greenable" infrastructure investments by cities}

Cities are key investors in infrastructure. Urban areas in 20 European OECD countries invested approximately USD 59 billion in 2010 in the transport, housing and environmental protection sectors. In most cities, transportation infrastructure accounts for the greatest share of urban capital spending; in others, such as France, housing infrastructure dominates this pool (Figure 1). However, maintenance and operational spending is not taken into account in these calculations; in reality, cities will thus spend more on green infrastructure than indicated here.

Figure 1. Gross capital formation (bn USD) in urban areas in European OECD-countries, 2010

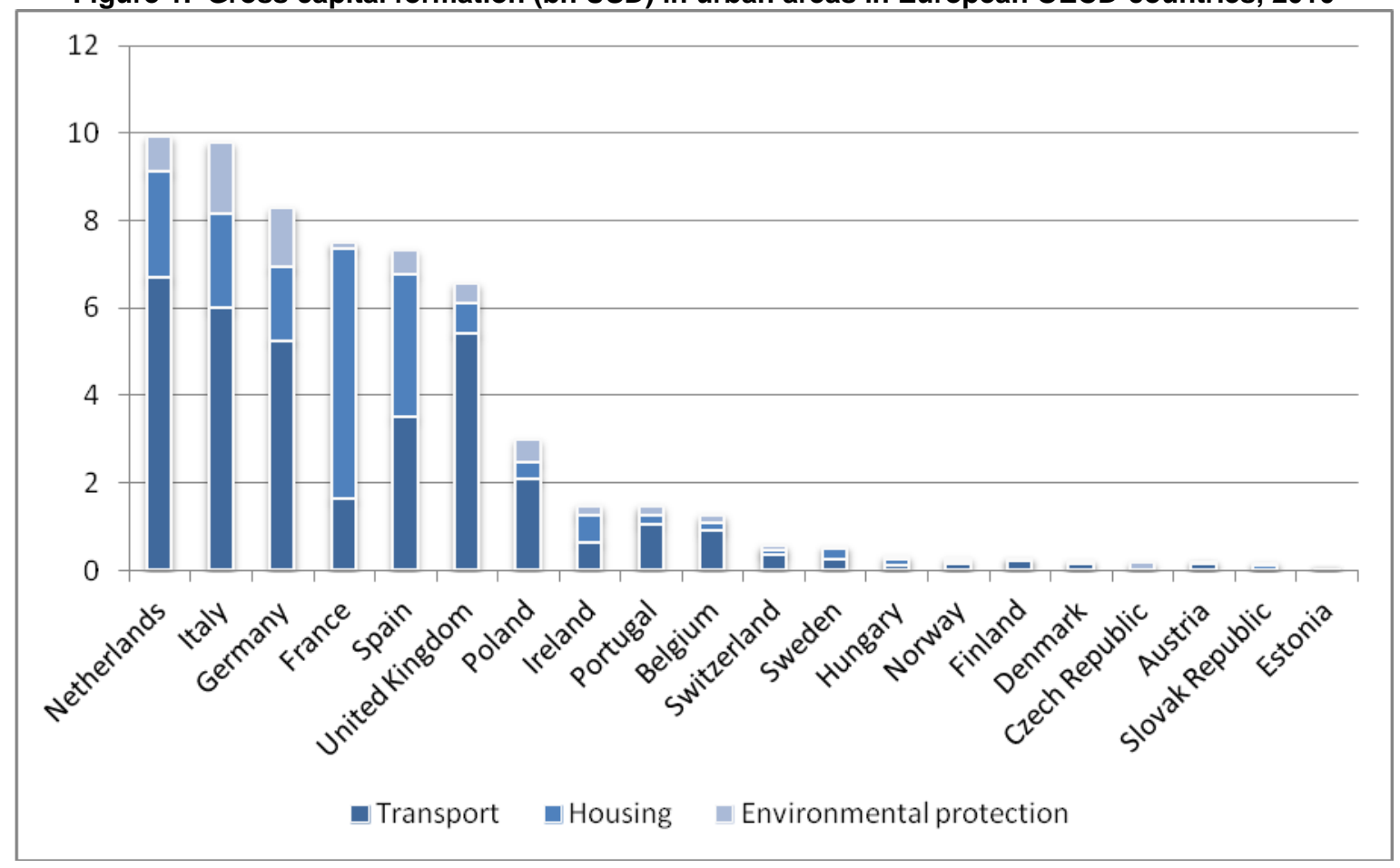

Source: Author's own calculation based on OECD National Account Statistics Database and OECD Regional Database.

Note: The columns refer to the functional classification of spending in national accounts: economic affairs, housing and community amenities and environmental protection. Transportation spending is included in the economic affairs category; the gross capital formation for this is considered to be transportation-related, as the other economic affairs spending (salaries, subsidies, etc.) do not relate to capital. Gross capital formation by local governments is corrected for the share of local government population that is living in predominantly urban areas in that country, in order to derive gross capital formation by cities. For Ireland, Poland and Sweden data for 2009 are used. 
Local governments spend an average of about $8 \%$ of their capital budget on environmental protection. However, this is generally not the main source of local governments' spending; gross capital formation by local government in OECD countries is mainly channelled to economic affairs, education, housing and general public services (Figure 2). In 2009, capital expenditure in environmental protection represented, on average, $7.6 \%$ of total local government gross capital formation, with large disparities among countries ranging from below $2 \%$ (e.g. Iceland, Denmark and Sweden) to almost $15 \%$ (e.g. Hungary and Greece) (Figure 3). While in some European countries (e.g. France, Netherlands, Norway and Sweden), capital expenditure in environmental protection is incurred almost entirely by the local government, in other countries (e.g. United Kingdom and Iceland), local government represents less than a third of total government expenditures in this sector (Figure 4). In decentralised countries, such as Spain or Belgium, regional government expenditures in environmental protection accounts for nearly a third of total environmental expenditure. On average, capital expenditure in environmental protection by local government represents $75 \%$ of total government expenditure in environment. Among main OECD member countries, France, Italy, Spain and Germany top the ranking of total gross capital formation in environmental protection by either local or general government (Figures 5 and 6).

Figure 2. Local government gross capital formation by function

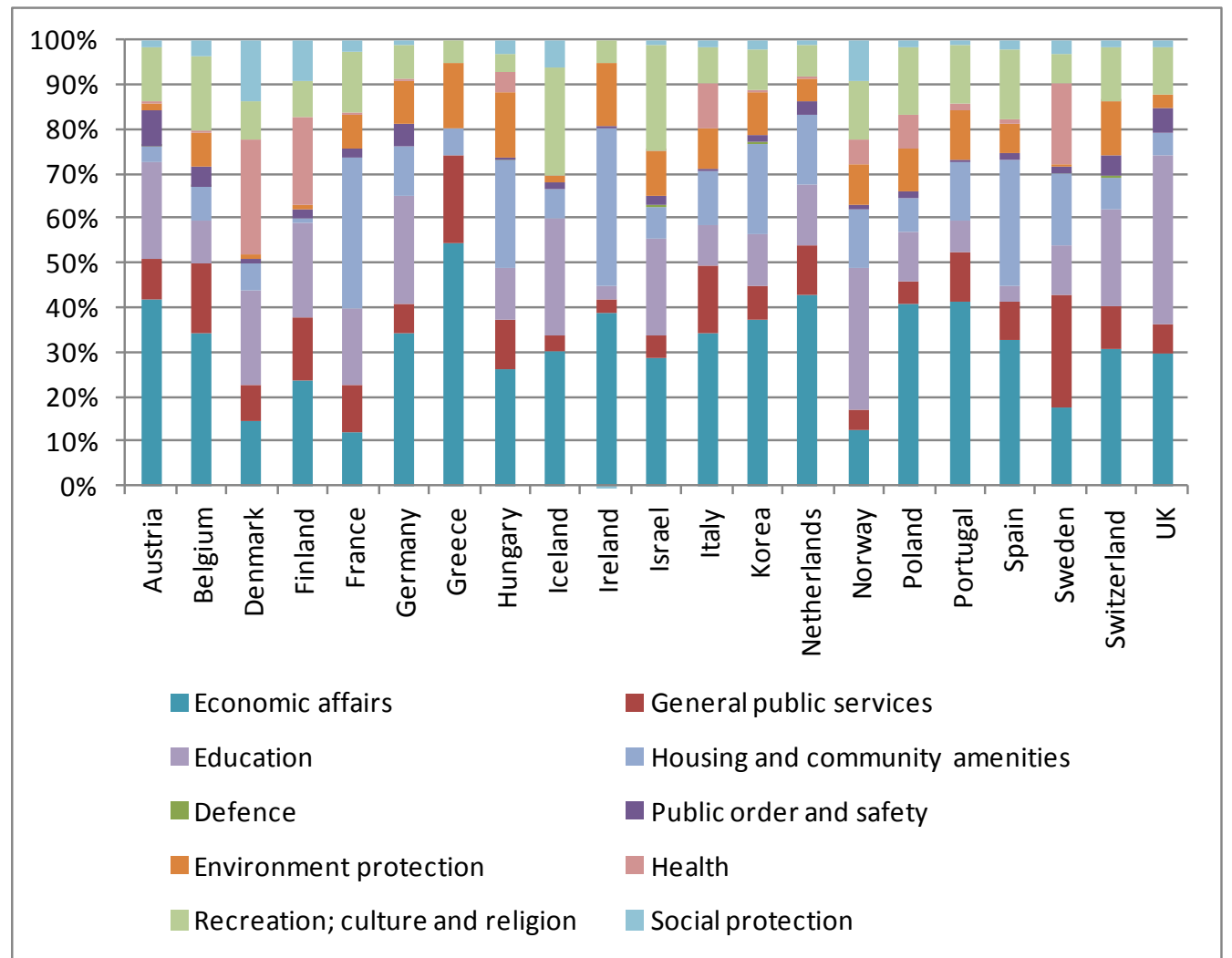

Source: OECD, National Accounts Database, 2009, http://www.oecd-ilibrary.org/economics/data/oecd-nationalaccounts-statistics na-data-en 
Figure 3. Gross capital formation in environmental protection by local government (as $\%$ of total local government gross capital formation) in 2009

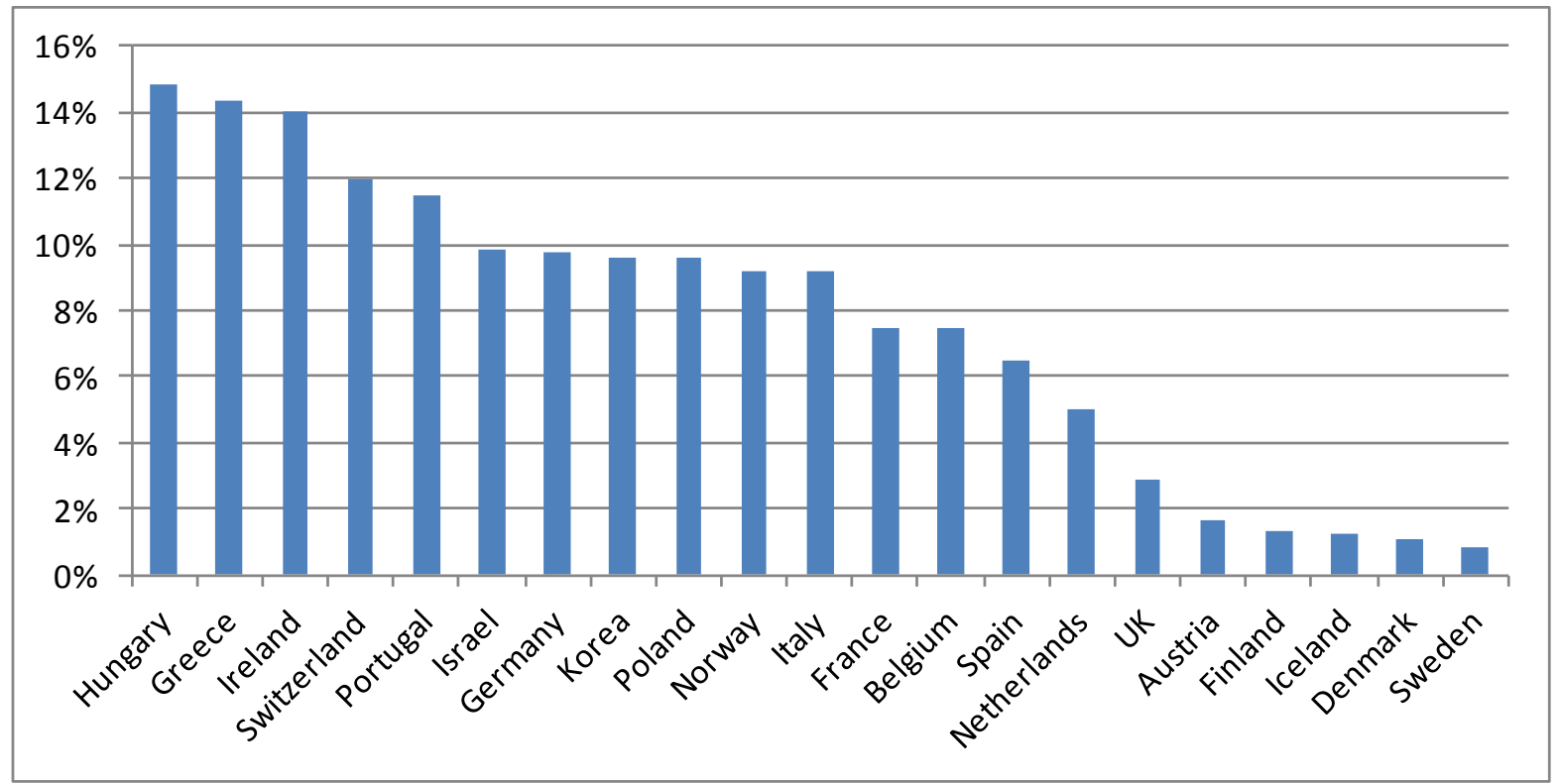

Source: OECD, National Accounts Database, 2009.

Figure 4. Gross capital formation in environmental protection by level of government, 2009

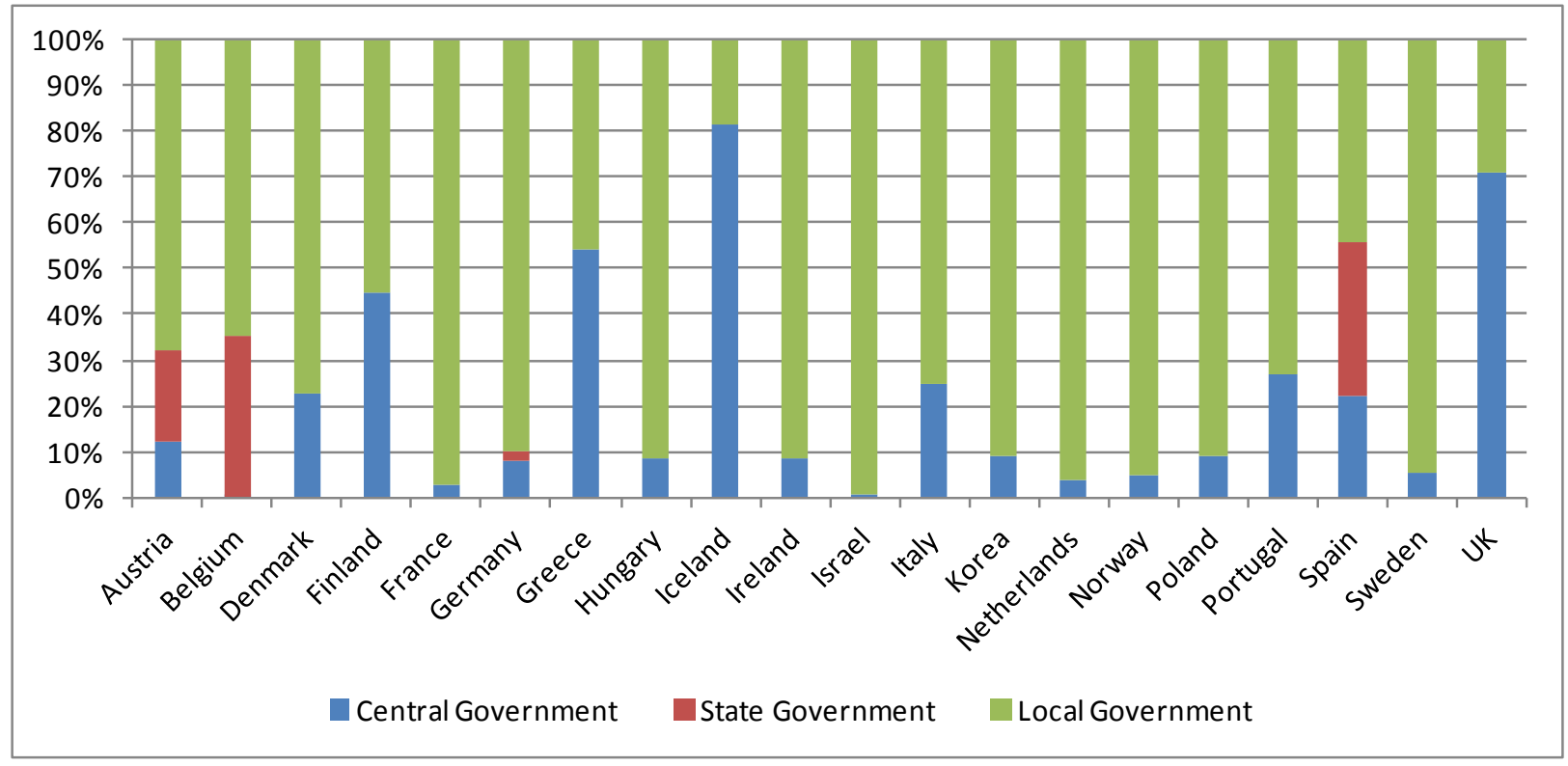

Source: OECD, National Accounts Database, 2009 
Figure 5. General government gross capital formation in environmental protection in USD (current prices, millions in 2009)

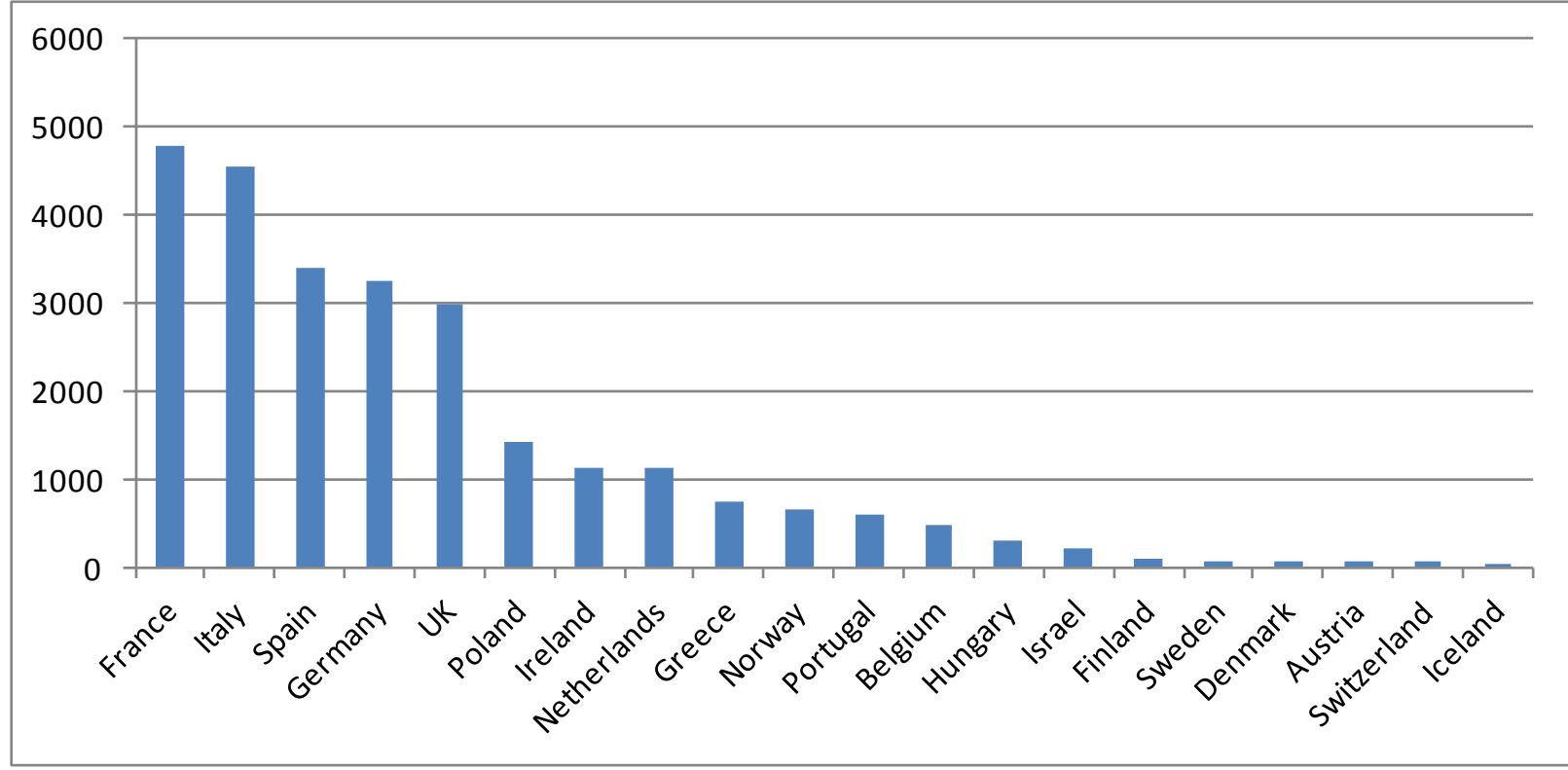

Source: OECD, National Accounts Database, 2009.

Figure 6. Local gross capital formation in environmental protection in USD (current prices, million in 2009)

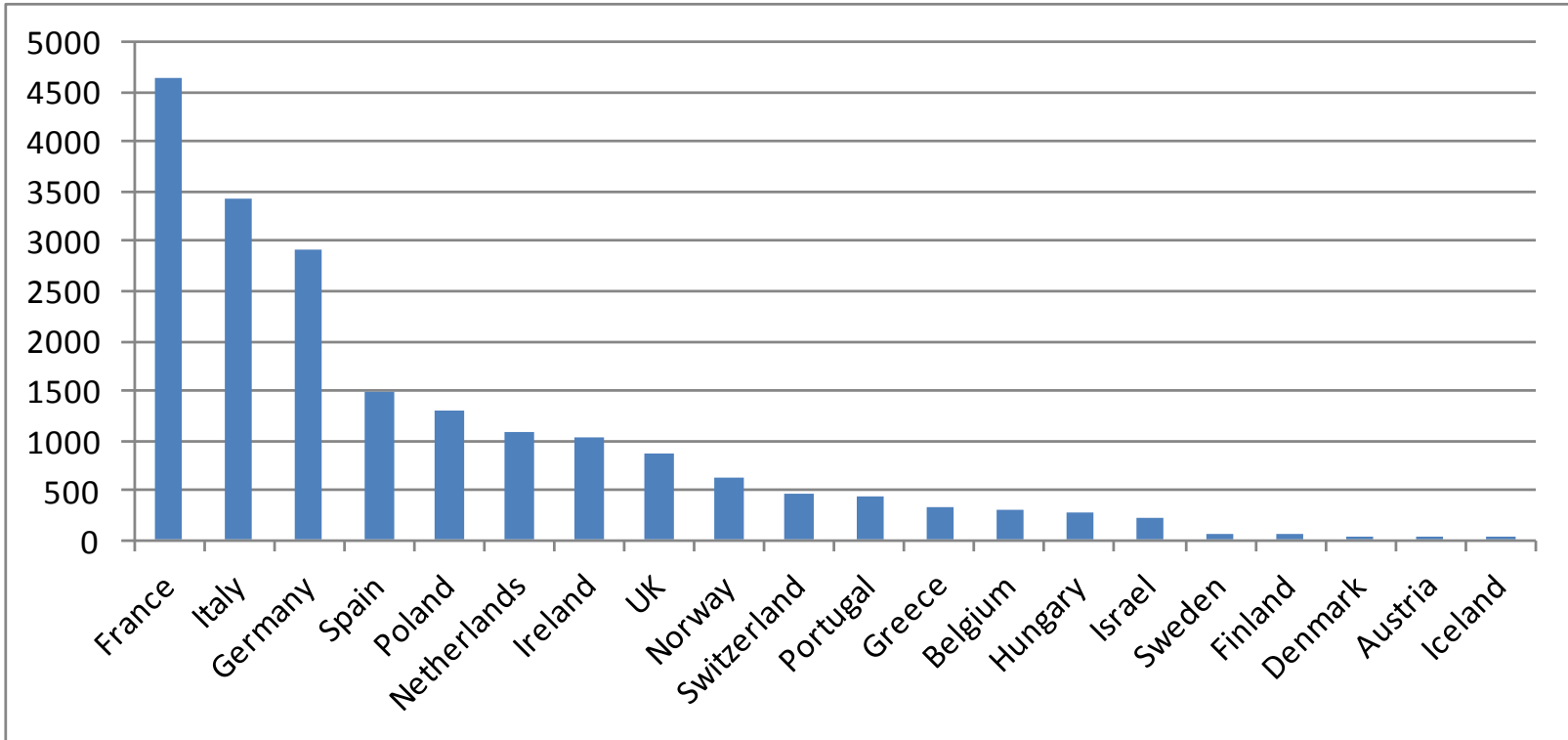

Source: OECD, National Accounts Database, 2009.

Urban spending in sectors with green potential represent between $10 \%$ and $45 \%$ of total urban expenditures (Figure 7). This means that cities have a relatively large margin of manoeuvring for greening these sectors (transport, building, water, waste and other environmental services). The margin is particularly high in Canadian cities like Montreal and Toronto, where they represent $44 \%$ of 
total city current and capital expenditures, mainly due to large shares in transport spending. These expenditures can stimulate green growth through employment opportunities: in the short term, during the construction phase of the infrastructure, and in the medium/long term, in maintenance or transport. The building sector can also represent important opportunities for green growth through employment in construction, development of markets for green building products, etc. Green growth projects in the building sector could also promote equity by improving housing conditions for low-income households. Box 1 presents concrete examples of budget items connected to transportation and building. Green spaces, parks management, environmental services, streets and sanitation, power and environmental protection - grouped together as "other environment" (Figures 7 and 8) - can also present green growth opportunities generally related to regular maintenance of green spaces or streets.

Figure 7. Expenditure shares of major cities by function, 2010

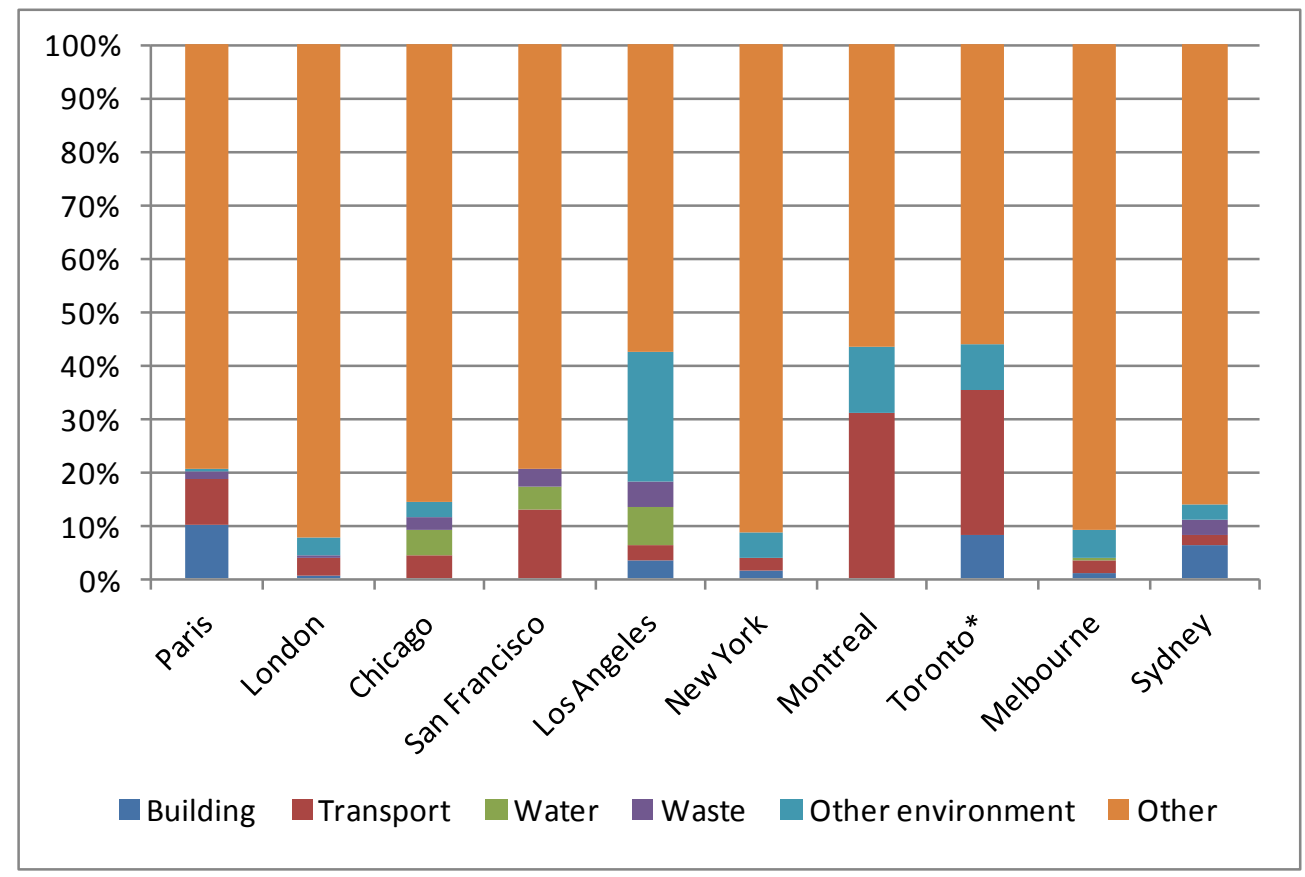

Source: Based on financial statements of cities on their respective websites, in 2010, except $\left(^{*}\right), 2009$. 
Figure 8. Expenditure shares in green growth sectors, 2010

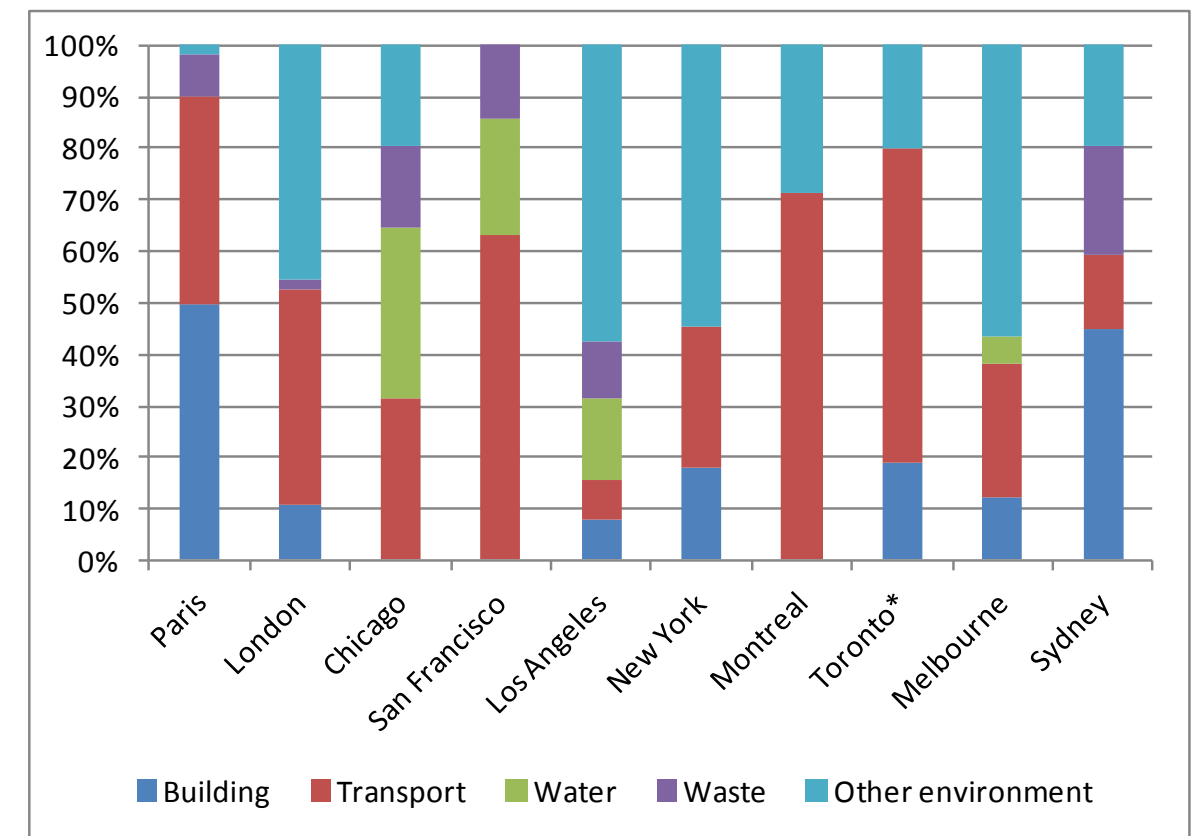

Source: City Council Financial Statements, in 2010, except $\left(^{\star}\right), 2009$.

\section{Box 1. Transport- and building-related green activities in cities' budgets}

Transport accounts for a large part of expenditures in sectors with green potential, and is generally related to transport planning and investment in transport infrastructure. For example:

- $\quad$ San Francisco is planning to build a multi-modal hub in the city's core; this Transbay Transit Center will provide expanded bus service to and from surrounding counties. The city also plans to expand the subway system to help reduce car use and ultimately greenhouse gas emissions.

- In Sydney, transport projects include a $200 \mathrm{~km}$ bicycle network designed to reduce overall congestion and increase the number of people choosing cycling as a safe, sustainable and healthier transport option. The city has allocated more than USD 70 million over four years to build this bicycle network. Sydney has also initiated plans to enhance access by public transport through regional and city programmes, such as the Green Square Transport Management and Accessibility Plan (TMAP) to reduce car ownership and reliance and improve accessibility by non-car travel mode in Green Square.

- $\quad$ Similarly, in Paris, expenditures in transport, amounting to EUR 257 million in 2010, were used to expand the subway system to the periphery and to improve the bicycle track network.

Building-related green activities include the following examples in the different city budgets:

- Sydney's major programme, "Retrofit of City of Sydney Portfolio" (to be completed in December 2012), aims to install metering and energy savings devices in all city of Sydney properties, to replace inefficient plant and equipment and to incorporate new technologies to improve environmental performance.

- Toronto's Tower Renewal Project is designed to drive broad environmental, social, economic and cultural change by improving the city's concrete apartment towers and the neighbourhoods that surround them.

- $\quad$ The City of London spent GBP 1.26 million in 2010 for its housing programme, created to improve homes and transform neighbourhoods by improving design quality, greening homes, promoting mixed communities and tackling empty homes. 


\section{Significant global funding needs}

Investing in green urban infrastructure is challenged by current global fiscal constraints. Resources are scarce, and public authorities in all levels of government must do more with less. This decrease in public investment flows hits sub-national governments - historically responsible for twothirds of public investment across the OECD - especially hard. Some fiscal stimulus packages (e.g. in the US and South Korea) incorporated urban green growth initiatives, providing more room for public investment in the short term. Since 2010, however, most OECD countries have attempted to curb public debt by reducing public expenditure. As a result, many cities around the world have been faced with local budget cuts due to reduced intergovernmental transfers and lower tax bases.

At the same time, global infrastructure needs are huge. According to OECD (2007), improving the world's infrastructure will require an estimated USD 35-40 trillion - i.e. USD 2 trillion dollars per year, or $2.5 \%$ of global GDP. Major sectors that need increased investment include road, rails, telecoms, electricity and water (water requires the largest investment of USD 16 trillion). Consistent with these projections, the International Energy Agency (IEA) estimates that meeting global population growth, especially for the BRIICS countries (Brazil, Russia, China, India, Indonesia and South Africa), requires an average investment of USD 48 billion per year until 2030 into the energy sector alone (IEA, 2011). IEA (2010) also estimates that a USD 46 trillion increase in global energy investment between 2010 and 2050 is needed to deliver low-carbon energy systems that yield cumulative fuel savings equal to USD 112 trillion. A considerable share of this investment is required in cities.

The urban infrastructure deficit in developing countries is particularly acute. A high proportion of the urban population in Africa and Asia, and a significant proportion in Latin America and the Caribbean, live in homes and settlements with little or no infrastructure (i.e. no all-weather roads, no drains, no piped water supplies and no provision for electricity). Most urban centres in developing countries, including many with several million inhabitants, also lack sewers. Removing the housing and infrastructure deficit in developing countries by 2030 would cost an estimated USD 6.3 trillion, including USD 700 billion for expanding housing and infrastructure for growing urban populations (Parry et al., 2009).

Greening urban systems is expensive and requires shifting of investments. Preliminary estimates of C40 (Cities Climate Leadership Group) city greenhouse gas emissions suggest (Hoornweg et al., 2011) that the total capital costs of infrastructure investments required to mitigate the group's emissions, status quo (i.e. without population growth), would be approximately USD 3 trillion. These investments, which include private sector government contributions, may take several years to realise. Individual calculations per city confirm the extent of these costs: London has estimated that meeting the Mayor's target to reduce carbon dioxide emissions by $60 \%$ by 2025 will cost about GBP 40 billion; and the Mayor's existing climate change mitigation programme is projected to cost about GBP 14 billion by 2025 (KPMG,, 2011). In addition, overviews of realised capital costs of urban green projects provide a more detailed presentation of costs associated with green cities (Table $1)$. 
Table 1. Capital costs of selected green projects in OECD cities

\begin{tabular}{|c|c|c|c|}
\hline Project & City & $\begin{array}{c}\text { Capital costs (USD } \\
\text { million) }\end{array}$ & $\begin{array}{c}\text { Annual GHG } \\
\text { savings } \\
\text { (ktCO2e) }\end{array}$ \\
\hline \multicolumn{4}{|l|}{ Transportation } \\
\hline Bus rapid transit & Vancouver & 39.2 & 1.8 \\
\hline Congestion charging & London & 244 & 120 \\
\hline Bike sharing & Paris & 132 & 18 \\
\hline \multicolumn{4}{|l|}{ Buildings } \\
\hline $\begin{array}{l}\text { Solar air heating } \\
\text { Energy }\end{array}$ & Montreal & 1.96 & 1.34 \\
\hline Solar centre receiver station & Seville & 41 & 110 \\
\hline Urban wind power & Toronto & 1.21 & 0.38 \\
\hline \multicolumn{4}{|l|}{ Solid Waste } \\
\hline $\begin{array}{l}\text { Source-separation and methane } \\
\text { production }\end{array}$ & Sydney & 75 & 0.36 \\
\hline Incineration-based CHP & Gothenburg & 453 & 205 \\
\hline \multicolumn{4}{|l|}{ Water/Wastewater } \\
\hline Biogass from sewage & Stockholm & 15 & 14 \\
\hline
\end{tabular}

Funding climate change adaptation in cities will require significant investment as well. Damages, especially to infrastructure, caused by climate change-related disasters are likely to pose increased costs for cities. Global climate change adaptation costs vary, but alone are estimated to be between USD 49 billion and 171 billion per year until 2030 (UNFCC, 2007), i.e. one or several hundred billion dollars a year (International Strategy for Disaster Response, 2009); cities will need to bear a large share of this cost.

Investment of this scale calls for a new focus on green funding and innovative solutions. Green infrastructure for cities requires upfront investments that may show benefits only in the long run and incur risks related to uncertainty over regulatory, economic and technological developments (e.g. energy prices and the cost of carbon dioxide emissions). Furthermore, these investments are constrained by limited size of urban projects and capacity at the urban level, as well as transaction costs of mobilising private finance. The inclination of cities and investors to focus on short-term priorities and concerns presents the key challenge: to develop viable business cases for investment in green urban infrastructure. A range of instruments can help to achieve this goal through green urban finance and innovative finance solutions (Table 2). A green focus on urban finance could mean property taxes that stimulate density, transportation fees that reduce car traffic, and fees that stimulate responsible water consumption. Public finance can also be used to leverage finance from private actors through loans, bonds and carbon markets; to create incentives for them to invest in sustainable infrastructure related to new development; and to get them involved in partnerships so government can benefit from private sector knowledge and experience in greening infrastructure. 
Table 2. Main financial instruments in the main green urban sectors

\begin{tabular}{|c|c|c|c|}
\hline & Transportation & Water /Waste & Energy \\
\hline Taxes & & Property tax & \\
\hline $\begin{array}{l}\text { Fees and } \\
\text { charges }\end{array}$ & $\begin{array}{l}\text { Congestion charges } \\
\text { Parking fees } \\
\text { High Occupancy Toll } \\
\text { lanes }\end{array}$ & Building permits & $\begin{array}{l}\text { Electricity user } \\
\text { fees }\end{array}$ \\
\hline Grants & $\begin{array}{l}\text { General grants with envi } \\
\text { services, matching grant }\end{array}$ & $\begin{array}{l}\text { ironmental indicators, specific grants for environmental } \\
\text { ts }\end{array}$ & goods and \\
\hline PPPs & Concessions and Private & Finance Initiatives (PFIs), energy performance contract & \\
\hline $\begin{array}{l}\text { Land-based } \\
\text { income }\end{array}$ & & $\begin{array}{l}\text { Development charges/impact } \\
\text { fees } \\
\text { Value capture tax } \\
\text { Higher density building rights } \\
\text { Tax increment financing }\end{array}$ & \\
\hline $\begin{array}{l}\text { Loans and } \\
\text { bonds }\end{array}$ & Loans and green bonds & & \\
\hline Carbon finance & Clean Development Mec & hanism/Joint Implementation, voluntary carbon offsets & \\
\hline
\end{tabular}

\subsection{Revenues and green cities: Getting the incentives right}

City and local government revenue sources are usually classified according to revenue types: tax revenues, fees and charges and intergovernmental grants. To assess the potential green impacts of these sources they further classified according to where their revenue base originates (i.e. transportation, building sector or other sectors).

Revenues from building and transport - the main source of urban revenues (Figure 9) - are mostly derived from transportation fees and charges (e.g. parking fees) and property taxes (see Section 1.3), or in the case of Montreal and Melbourne, from state grants. In Sydney, user charges and fees represent $17 \%$ of total revenues, of which $40 \%$ comes from parking meter income and $11 \%$ from parking station income. Other sources of revenues include taxes for waste management, representing $12 \%$ of total revenues from taxes for the City of Paris, and charges for water services, representing between $4 \%$ and $7 \%$ of total revenues in US cities such as Los Angeles, San Francisco and Chicago. 
Figure 9. Revenues of cities by function, in \%, 2010

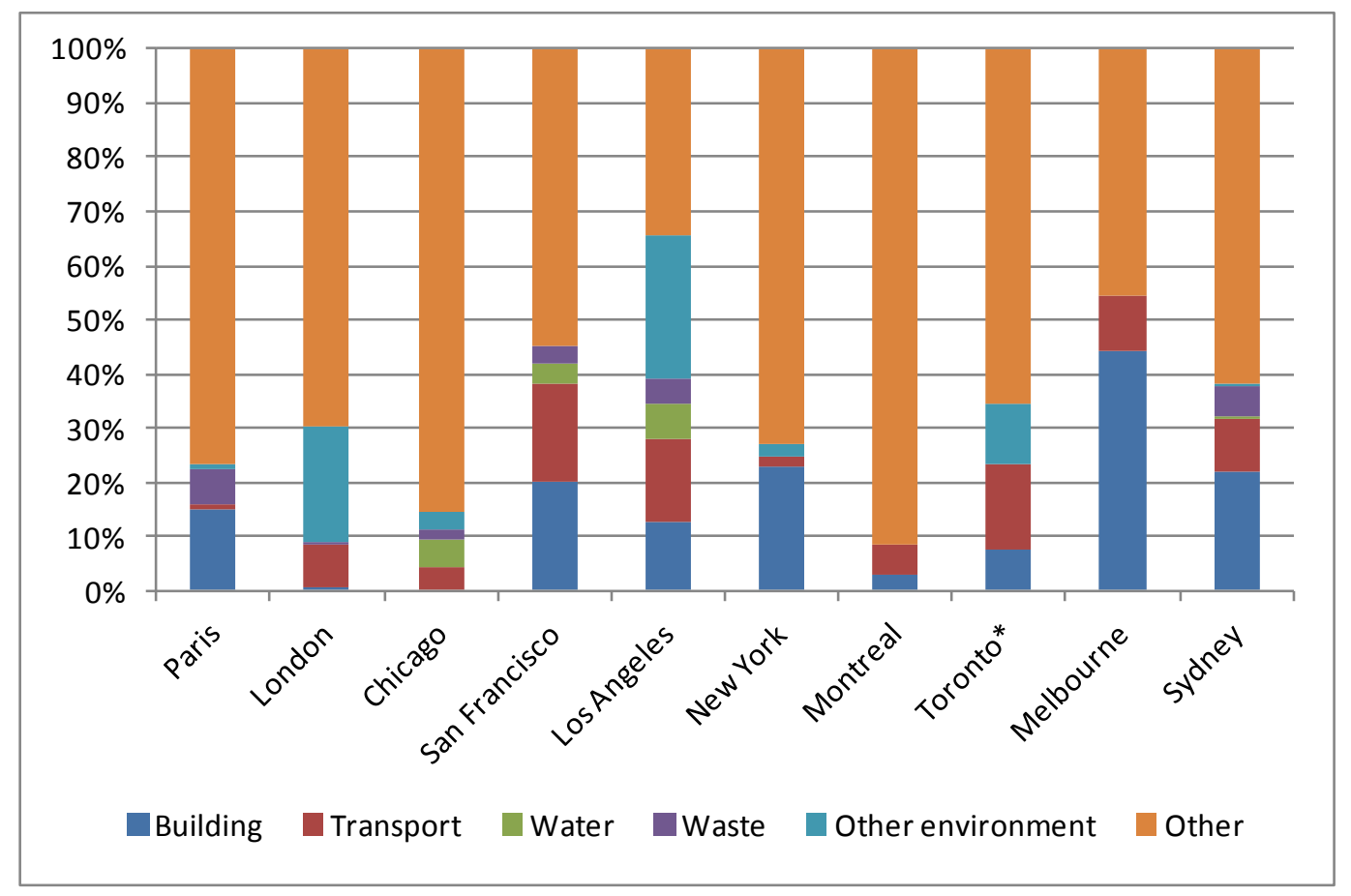

Source: City Council Financial Statements, 2010; except $\left(^{\star}\right)$ : City Council Financial Statements, 2009 as found on the different cities' websites.

Urban revenue sources can either help or hinder green policy priorities. Fiscal policies operating within and across levels of government - should be reconsidered to identify unintended consequences to green growth and sustainable development (see Corfee-Morlot, et al., 2012). At a minimum, this means eliminating the anti-green bias of some existing local tax provisions and the perverse incentives created by many environmentally harmful subsidies. Three broad principles are key to identifying an appropriate mix of green revenue reforms:

- $\quad$ Policy coherence across levels of government is critical. Reforms to urban revenue sources need to be designed considering the broader policy framework. The greener the national framework, the easier it will be to address city-specific challenges and to ensure coherence and consistency between national and local policies. At times, national-level initiatives may obviate the need for local action; in other cases, they may create new opportunities for cities to act. Furthermore, if co-ordination is poor, national and local initiatives can hinder each other's effectiveness. The national framework is particularly important for establishing price signals for non-localised environmental externalities, such as greenhouse gas emissions.

- A holistic approach is necessary. Efforts to green urban revenue sources may have undesirable distributional consequences. These concerns should be addressed in the context of the entire tax and benefit system, rather than trying to ensure that each individual policy measure serves both environmental and equity objectives. Thus, changes to transfers or nonenvironmental taxes and charges may be needed to offset the distributional impact of reforms seeking to green some revenue sources. 
- $\quad$ The instruments should be sophisticated but the package should be simple. The design of specific instruments will in many cases need to be quite sophisticated in order to avoid creating perverse incentives. Congestion charges, for example, will likely be more effective if they vary according to vehicle type, peak hours, etc. Nevertheless, it is important to keep the overall policy package as simple as possible. An overly complex system of environmental taxes, charges and fees makes impact assessment more difficult and raises the risk of unintended interaction effects or perverse incentives.

\section{Property taxes and development fees}

Property taxes should be designed to limit urban sprawl. Throughout the OECD, local governments earn the most revenue from property taxes. The impact of these taxes on land use, density and urban sprawl depends on policy choices: what is included and excluded from the tax base, how property value is defined for different classes of property (e.g. residential, multi-residential, farm, commercial and industrial properties), what percentage of the value is taxable, and how effective tax rates vary within and among property classes. ${ }^{2}$ By altering the relative price of property, these taxes can influence a number of decisions regarding property improvement, size and location - and ultimately increase or decrease urban sprawl (Deskins and Fox, 2010). Decreasing sprawl through property taxes requires the following priority actions (see Section 1.3 for a more in-depth analysis):

- Eliminate policies that favour single-family homes over apartments. Policies that favour single-family homes over multi-family properties result in less dense development. Perverse incentives are created when single-family residential properties are offered lower taxes than higher-density properties of the same value (Haveman and Sexton, 2008).

- $\quad$ Tax the land value, not the property. When property taxes are based on land value, rather than buildings or other improvements to the property, owners have an incentive to develop the land to its most profitable use. Replacing a traditional property tax with a land-value tax, or a split-value tax that includes higher rates for land value and lower rates for structures or other improvements (as implemented by some municipalities in the US state of Pennsylvania), could encourage development in the urban core.

Development fees can discourage sprawl and fund infrastructure. In several countries, municipalities have the discretion to negotiate infrastructure improvements with developers when the municipalities make new land available for urban development. Such contributions from developers could be designed to discourage sprawl if they cover the real costs of infrastructure provision to the new site. This could be achieved through the following approaches (a more in-depth analysis in section 2.3):

- Impose area-specific development charges - a one-time levy on developers to finance the growth-related infrastructure investments needed to serve the new development or, in some cases, redevelopment. This type of pricing policy can be an effective planning tool that renders developers fully responsible for their project costs, promotes the need to correct for the external costs of development by increasing land cost, and generates funds for infrastructure development and compensation programmes. For example, the extension of the metro-line in Copenhagen was financed through fees from development of the Ørestad area of Copenhagen (OECD, 2009).

- $\quad$ Sell additional building rights. In São Paolo, for example, the building rights for additional floor space on the top of existing buildings that exceeded normal maximum density were sold in areas authorised for higher-density development. Similar mechanisms can be found in the 
state of Maharashtra, India, where the maximum floor space index was increased, and the extra floor space sold to developers. Both initiatives have generated additional infrastructure funding while increasing urban density. The sale of additional building rights is particularly relevant for growing cities with scarce land, as long as construction and safety standards are taken into account (a more in-depth analysis is provided in Section 2.4).

- Tax low-density development. France introduced a scheme in 2010 that taxes development that does not meet minimum density requirements. The City of Austin, Texas in the US has introduced a special transportation levy on all municipal utility bills, based on the estimated average number of daily motor vehicle trips per household, in effect penalizing less-dense development.

\section{Transportation fees and charges}

Transport fees should discourage car use and encourage public transit and non-motorised travel. While national or state/provincial governments control most transportation-related taxes, local governments often control transportation fees and charges. The following instruments have been used successfully to reduce the share of car traffic, reduce emissions, and raise funding to finance local transportation infrastructure:

- Congestion charges are fees for road use that are applied exclusively or more intensely during peak traffic periods. Congestion charges have reduced air pollutions, including a decrease in carbon dioxide emissions of up to $19.5 \%$ in the cities where they have been (Beevers and Carslaw, 2005) (Table 3). Higher polluting vehicles may be charged higher rates (e.g. as in Singapore and Milan), which more closely ties the congestion charges to greenhouse gas reduction goals. Some cities (e.g. London) use the revenue from congestion charges to finance urban public transport.

Table 3. Impacts selected urban congestion charges

\begin{tabular}{|lllll|}
\hline Introduced & London & $\begin{array}{l}\text { Stockholm } \\
2006\end{array}$ & $\begin{array}{l}\text { Singapore } \\
1975-98\left(2^{\text {nd }}\right. \\
\text { generation) }\end{array}$ & $\begin{array}{l}\text { Milan } \\
\text { n.a. }\end{array}$ \\
\hline $\begin{array}{l}\text { Reduction CO2 } \\
\text { emissions (in \%) }\end{array}$ & $19.5 \%$ & $13 \%$ & n.a. & $9 \%$ \\
\hline Period of effect & $2002-03$ & January-July 2006 & January-December \\
\hline Other effects & $\begin{array}{l}\text { Reductions of } \\
\text { emissions (NOx, } \\
\text { PM10), car traffic }\end{array}$ & $\begin{array}{l}\text { Reductions of } \\
\text { emissions (NOx, } \\
\text { CO, PM10), } \\
\text { vehicle passages }\end{array}$ & $\begin{array}{l}\text { Reductions of car } \\
\text { traffic and car share } \\
\text { modal split. }\end{array}$ & $\begin{array}{l}\text { Reductions of } \\
\text { emissions (PM10, } \\
\text { NOx) and traffic } \\
\text { volumes. }\end{array}$ \\
\hline
\end{tabular}

Source: OECD (2010b), Cities and Climate Change, OECD, Paris.

- Variable parking fees and taxes can reduce car trips and encourage public transportation use (OECD, 2010b). Parking fees can even more effectively discourage car use by charging higher rates in congested areas or during peak hours (e.g. as in Los Angeles and New York City), especially if the parking tax revenue is used to finance public transit.

- High Occupancy Toll (HOT) lanes encourage carpooling by charging a toll on vehicles with less than a minimum number of occupants (usually two or three). The effectiveness of HOT lanes is mixed, considering the relatively high costs for collecting tolls: for example, a major 
HOT lane in Los Angeles has operating expenses totalling 27\% of gross revenues (Dachis, 2011).

\section{Utility fees}

Utility fees should encourage resource conservation. Water, waste and energy fees should be used to signal the scarcity of the resource being consumed. This will discourage resource consumption and waste generation, which can in turn increase efficiency and revenues. Many local governments already do link fees to actual consumption of water and energy and actual generation of waste, but many others could strengthen this link to promote conservation and less waste. Fees tied to resource consumption or waste generation can fund service delivery and infrastructure improvements, although they are best considered as part of a funding package that also includes taxes and transfers.

\section{The impact of national policy}

National policies' impacts on local incentives should also be reviewed. As noted above, national government policies can support or undermine local green development. It is important to identify and remove perverse incentives in order to encourage infrastructure investment in line with sustainable development and green goals.

- Remove national obstacles to local incentives. National regulations may in some cases constrain local governments' ability to act. For example, several countries (e.g. Denmark) require national government approval for cities to use revenue from congestion charges, as they are considered new taxes.

- $\quad$ Strengthen local authority to act. National governments could also introduce requirements and standards for infrastructure cost recovery (e.g. Netherlands).

- Design general grants to cities to compensate for environmental service provision and opportunity costs of environmental preservation. A large share of many cities' revenues comes from development rights, building permits and the income related to new development. Some national governments have begun to compensate local governments for these opportunity costs by revising their grant allocation formulas to account for environmentally protected municipal land.

- $\quad$ Provide specific-purpose and matching grants to align local action with national green growth and sustainable development goals. Green urban infrastructure investments are often public goods with effects beyond local governments; intergovernmental grants would therefore have to internalise these externalities, which can be done through specific purpose grants. A way to align national and urban objectives consists of matching grants, which depend on co-funding by the local government that receives the grant. This reduces the marginal cost of investment for local governments and therefore increases the level of goods they are willing to provide. For example, Portuguese national grants reward municipalities for designating Natura 2000 sites and other protected areas within their boundaries, representing $5 \%$ of total money allocated through this grant. Several Brazilian states allocate state tax revenues to municipalities based in part on the amount of land municipalities set aside for environmental protection (OECD, 2010b). 


\subsection{Revenue and green cities: The case of the property tax}

Property taxes represent the largest tax revenue source of local governments throughout the OECD and can have an impact on land use. Property taxes are determined by multiplying a tax rate (or series of tax rates) times the tax base. A number of policy choices regarding the structure of the property tax can have an impact on land use: what is included and excluded from the tax base, how property value is defined for different classes of property (e.g. residential, multi-residential, farm, commercial and industrial properties), what percentage of the value is taxable, and how effective tax rates vary within and between classes of property. Property taxes can influence a number of decisions by altering the relative price of property. Specifically, it can influence choices about where to locate, whether to improve one's property, and what size dwelling to live in. These decisions, in turn, can influence urban sprawl (Deskins and Fox, 2010).

Research on the impact of the property tax on urban sprawl is mixed. Theoretically, the property tax can have two different effects on sprawl (Brueckner and Kim, 2003). The improvement effect suggests that, all else being equal, a property tax based on market value is expected to result in a reduction in density. Where the tax is levied on the assessed value of property (land and improvements), any investment (such as a building) that increases the value of the property increases its assessed value and thereby its tax. ${ }^{3}$ Higher property taxes are thus expected to provide an incentive for less densely developed projects - scattered single-family houses rather than apartment buildings. Lower densities mean that the city is likely to expand in a way that is socially inefficient (Brueckner, 2001). ${ }^{4}$ In contrast, the dwelling-size effect would lead to a reduction in urban sprawl. If the tax is partially shifted onto consumers it would lead to a reduction in the size of homes and result in a more densely populated city (Brueckner and Kim, 2003).

Few empirical studies of the impact of the property tax on urban sprawl have been undertaken. Deskins and Fox (2010) report on two US studies, which indicate that the dwelling effect exceeds the improvement effect. One study, using data from 448 urbanised areas with a population of at least 50000 , shows that higher effective property tax rates reduce sprawl (Song and Zenou, 2006). According to their estimates, a $1 \%$ increase in the effective property tax rate leads to a reduction of about $0.4 \%$ in the spatial extent of an urban area. A second study, using data from 306 Metropolitan Statistical Areas (MSAs) in 1990 and 2000, confirms that higher average property tax rates result in less sprawl (Marshall, 2008). A more recent study by Song and Zenou (2009), however, uses a database for central cities and suburbs in 445 urban areas in the US and finds that a lower property tax rate in the suburbs compared to the central city is associated with more expansive urban growth and a higher level of population and employment decentralisation.

To the extent that property tax differentials are matched by differentials in expenditures on public services, they should not result in a distortionary impact on location or land use. The property tax cannot be regarded as a direct user fee that individuals pay directly for the services they receive, with both tax rates and service levels determined locally; yet, the property tax may loosely be considered a benefits tax to the extent that the public services provided to the property owner enhance the value of the property and result in higher property taxes. Where such "matching" does not occur, however, there will be a pattern of positive and negative subsidies that will influence urban development patterns, usually in a way that worsens it.

\section{Getting rid of incentives that favour single-family homes over apartments}

Eliminating policies that favour single-family homes could help to stimulate urban density. In most countries around the world, the property tax favours residential single-family homes over multiresidential properties (Bird and Slack, 2004), as is the case in Toronto and New York City (Box 2). 
Favourable treatment of single-family residential properties is achieved in three ways. First, where market value assessment is used, the system deliberately under-assesses single-family residential property compared with apartments and commercial and industrial property of comparable value. Second, many jurisdictions have legislated lower tax rates on single-family residential property than on other types of property. Third, governments often provide property tax relief to residential property owners (and in some cases to tenants) in the form of tax credits, homeowner grants or tax deferrals. These measures are not generally made available to other types of properties (Haveman and Sexton, 2008).

\section{Box 2. Disincentives to urban density: The case of Toronto and New York City}

The City of Toronto is permitted by provincial legislation to levy variable tax rates for seven different classes of property: residential, multi-residential, commercial, industrial, pipelines, farms and managed forests. Optional classes that municipalities can choose include new multi-residential, office buildings, shopping centres, parking lots, professional sports facilities and large industrial properties (Bird et al., 2012). Tax rates are lowest on residential properties and significantly higher on multi-residential, commercial, and industrial properties. Toronto has exercised the option granted by the provincial government to tax new multi-residential properties at the same rate as residential properties, but existing multi-residential properties are taxed at 2.6 times the residential rate.

New York City uses four classes of property for property tax purposes. Class 1 includes most residential properties of up to three units, vacant land zoned for residential use in boroughs other than Manhattan, and most condominiums that are under three stories. Class 2 includes all other properties that are primarily residential such as cooperatives and condominiums. Class 3 includes property with equipment owned by a gas, telephone or electric company. Class 4 includes all commercial and industrial properties such as offices, factory buildings and vacant land that do not qualify as Class 1 . Not only do tax rates differ by class, but the ratio of assessed value to market value also differs by class. Although the tax rates are somewhat higher for residential single-family properties (Class 1 ), the ratio of assessed value to market value is only $6 \%$ for Class 1 and $45 \%$ for the other three classes.

Other design features in the property tax might also favour single-family homes, such as property tax limits. For example, property tax relief schemes, especially for single-family homes, are common in North America and include credits against income taxes for property taxes paid (known as "circuit breakers" in the US and "property tax credits" in Canada), tax deferrals for the elderly, phase-ins of property tax increases, and reductions or cancellation of property taxes that are unduly burdensome. A few Canadian provinces have introduced a capping mechanism for residential properties whereby property tax increases arising from a reassessment are capped at the rate of inflation or some other percentage. Capping is much more prevalent in the US, however, where over 20 states have implemented some form of property tax assessment limit. In some states (e.g. Arizona, Michigan and California), these limits apply to all property classes; in other states (e.g. Colorado and New Mexico), they apply only to residential property; but in many states (e.g. Florida, Georgia, Illinois and Texas), limits only apply to single-family homes or homesteads and not to multi-residential units (Haveman and Sexton, 2008).

\section{Land taxation: Which alternative discourages sprawl?}

An alternative to a property tax based on both land and improvements is a tax based only on the value of the land (i.e. land tax, also known as "site value tax"). Based on the writings of Henry George (1879), a land tax is thought to be the most efficient because it does not discourage investment in new buildings. In principle, a levy on land taxes location rents (the returns from a particular location regardless of the improvements to the site). Since improvements to land (such as structures) are not taxed, the owner has an incentive to develop the land to its most profitable use. A site value tax would thus not discourage investment in the same way as a property tax on land and buildings. 
A land tax is considered neutral with respect to timing, location and density of development (assuming the tax base reflects the highest and best use of the property). Although it is neutral with respect to the above factors, a move from a property tax to a site value tax would likely increase density and curb urban sprawl: lowering the tax on structures will encourage more structures on a given land area and lead to greater density.

Although exclusive local land taxes are very rare, some local governments tax land separately via their property tax system. For example, some municipalities in Pennsylvania use a split rate system that taxes land more heavily than improvements. The ratio of tax on land values to tax on improvements ranges from 1.66:1 to 30:1 among the 16 communities that levy a split rate. Empirical evidence on the impact of land value taxation on development in the US is mixed, however. Mathis and Zech (1982) identified no relationship between the split-rate tax and the level of building activity across Pennsylvania communities. Bourassa (1990) found that the split-rate tax had a significant impact on residential building activity in Pittsburgh but not the two other cities studied. According to Oates and Schwab (1997), the split-rate tax increased building permit activity when the City of Pittsburgh reformed its property tax in $1979-80$ by raising the tax rate on land to more than five times the rate on structures. Although the authors conclude that the subsequent increase in building activity was largely attributable to a shortage of commercial space, the move to greater taxation of land is thought to have played a role. By increasing land taxes, which are neutral in terms of development decisions, the city was able to increase its revenues without increasing other taxes that could have had a distortionary impact on development decisions. Plassmann and Tideman (2000) also found that a split-rate tax in Pennsylvania resulted in a 3 to $4 \%$ increase in residential construction.

Land value taxation scores well in terms of efficiency. However, problems arise in its implementation: administration of the land tax can be difficult. Accurate land valuation presents a challenge to assessors because most urban real estate sales combine the value of land and improvements. Site value taxation requires the subtraction of the value of the improvements from the value of the property as a whole in order to derive an assessed value for the land. For this reason, some consider such taxation to be unacceptably arbitrary. On the other hand, some authors have argued that valuation of land alone is probably easier than valuation of property (Netzer, 1998): instead of assessing the value of land and improvements and then subtracting the value of improvements, site values per square metre could be estimated directly from sales and demolition records. 


\section{PRIVATE FINANCE AND GREEN URBAN INFRASTRUCTURE}

Private financing could fill the funding gap for many urban green infrastructure projects. For private finance to be a solution, three conditions would have to be met: a market for green urban investment projects, good return on investment and limited risk. Several instruments have been applied to attract private finance for urban green infrastructure. Private sector involvement in urban green infrastructure can take the form of public-private partnerships (PPPs), whereby the long-term risk is transferred to the private sector. Another instrument, tax increment financing, uses tax revenues to attract private finance. Alternatively, real estate developers can pay for the infrastructure needed to connect new development to existing infrastructure; this has taken the form of development charges and impact fees in North America, but similar instruments can also be found elsewhere in somewhat different forms. Asia makes extensive use of value capture taxes, aimed to seize part of the value increases of real estate due to new nearby infrastructure development. Finally, loans, bonds and carbon finance are instruments used (and that could be used more) to attract private finance.

\subsection{Conditions for private finance}

It is not possible to engage the private sector if there is no market for urban green projects; and if there is a lack of appropriate projects, the size of the market might be too small. In deciding on their investment portfolio, each private investor considers the trade-off between projected return on investment and risk. To gain the interest of private investors, urban green infrastructure projects need to be marketable and promising with regard to returns and risk: high potential yields or limited risk, or both.

Relatively limited market size might pose a challenge for private financing of urban projects. The potential market for urban green investment projects is small and fragmented. Attracting private investment, such as large loans or issuing of bonds, often requires the assistance of intermediaries or banks, which are subject to economies of scale. Small investment projects could mean prohibitively large transaction costs. With less frequency of investment projects at the city level than at the country level, capacity building for attracting private finance and contract negotiation for small urban development is also more challenging. This will be less problematic for large metropolitan areas, but smaller cities might benefit from pooling projects and capacity when mobilising private finance.

The relatively high cost of clean technologies can make it appear less attractive as an urban investment. Returns on green urban investment are often lower than alternative investment options. In many sectors, clean technologies are still in development, and the negative externalities of dirty industries are not always taken into account; this means that dirty technologies and sectors are favoured. In the energy sector, for example, only a limited number of countries have introduced carbon taxes to internalise negative externalities of fossil fuels, while many countries still have fuel subsidies that stimulate fossil fuel consumption. As a result, the costs of generating energy from coal or natural gas are still considerably lower (up to five times depending on the technology) than from renewable energy sources, even if the price of clean energy seems to drop quickly (WEF, 2010). ${ }^{5}$ Even if the returns of investment could be high, the benefits might spill over to other actors leading to under-investment from a societal point of view. Policy must take this spillover into account.

High risk associated with newer technologies can discourage financing options for urban green projects. In some sectors, technological uncertainty can translate to risk of investment in urban green projects. Risk profiles vary for different technologies and their stages of development; the technology development stage determines which type of financing is most appropriate. For example, venture 
capital financing is generally suited for unproven and untested technologies, while project finance is used for mature technologies, such as wind and solar power. Government-supported policies thus need to be tailored to the stages of a technology's development. Financing methods also depend on the project phase. Maturity of technologies and types of financing available are reflected in risk-return profiles of urban green investment opportunities. Thus, urban green projects with high capital intensity and high technology risk will be most difficult to finance.

\subsection{Involving the private sector through public-private partnerships}

The notion of public-private partnerships is multifaceted and covers a wide diversity of contractual agreements characterised by different risk-sharing and financing schemes, as well as different organisational forms - from management contracts to the Private Finance Initiative (OECD, 2008). PPPs are broadly defined as long-term contractual agreements between a private operator/company (or a consortium) and a public entity, under which a service is provided, generally with related investments (Saussier et al., 2009). Fundamental to this funding approach is the private partner's both long-term relationship with the public partner and assumption of some investment risk. The type of PPP arrangement determines the private operator's level of participation, exact role and involvement in the project's different stages (design, completion, implementation and/or funding). Unlike traditional public sector procurement, where the private contractor simply designs and/or builds what the public sector orders, PPPs involve a process in which private operators bid for a contract to design, finance and manage the risks involved in delivering public services or assets. In return, the private contractor receives fees from the public body and/or user tolls for the long-term operation and maintenance of the asset.

Two families of PPPs - concessions and private finance initiatives (PFIs) - differ regarding the private operator's remuneration schemes. For concessions, payments are usually made by users or are substantially connected to the number of users (e.g. shadow tolls). As a consequence, the private operator bears the demand risks because revenues are directly and substantially connected to the consumption level. In contrast, payment for PFIs is based on making the infrastructure available and is usually affected by the capabilities of the operator to meet performance targets. Consequently, the demand risk is more extensively transferred in concessions than in PFIs (see Annex I for a more detailed analysis of promises and pitfalls of PPPs).

Public-private partnerships can be either solicited or unsolicited, depending on who initiates the project. For a solicited project, the competent authority (central or local government) identifies a potential PPP project and solicits proposals from the private sector. For an unsolicited project, the private sector identifies a potential PPP project and requests designation of the project as a PPP from the competent authority. In this case, the concessionaire is selected under a competitive bidding process, although the initial proponent (the private actor who proposed the project) may obtain extra points in the bid evaluation. Not all countries accept unsolicited project initiation, but the following countries have participated in this type of PPP: Chile, India (sub-national), Pakistan, Philippines, Russian Federation (sub-national), United States (sub-national), and South Africa. Solicited projects cost governments considerable time and money to initiate, whereas unsolicited projects benefit from the efficiency of the private sector and their assumption of associated costs and risks. As a result, in countries where both solicited and unsolicited projects exist (e.g. South Korea), unsolicited projects may be favoured. Unlike unsolicited PPPs, however, solicited projects can be implemented in line with a government's overall infrastructure investment plan and priorities. For this reason, the government of South Korea has recently made efforts to promote more solicited projects.

Cities often use PPPs to achieve their green infrastructure objectives. Several projects identified as "best practice" projects by the C40 are governed by PPPs (Table 4). The different types of contracts 
indicated for the PPP projects show the diversity of contractual practices among these various cases. Alternative modes of governance (e.g. in-house, procurement, public) are also represented within this sample of projects. Considering this diversity, it is difficult to provide generic conclusions about the efficiency of PPPs: much depends on institutional, technological and economical circumstances. This is also illustrated by the case of the Eco-Stadium of the City of Nice (Box 3).

Table 4. C40 "best practice" projects

\begin{tabular}{|c|c|c|c|c|c|}
\hline & Activity & City & Country & Governance & Type of contract \\
\hline \multirow{12}{*}{ Transport } & \multirow{10}{*}{ Bicycle sharing } & Paris & France & PPP & Concession \\
\hline & & London & UK & PPP & \\
\hline & & Barcelona & Spain & PPP & \\
\hline & & Oslo & Norway & PPP & \\
\hline & & Lyon & France & PPP & \\
\hline & & Stockholm & Sweden & PPP & \\
\hline & & Brussels & Belgium & PPP & \\
\hline & & Seville & Spain & PPP & \\
\hline & & Dublin & Ireland & PPP & \\
\hline & & Copenhagen & Denmark & NGO & \\
\hline & Bicycles paths & Bogota & Columbia & In-house & \\
\hline & Congestion charge & Stockholm & Sweden & $\begin{array}{l}\text { Procuremen } \\
t\end{array}$ & \\
\hline \multirow{8}{*}{ Energy } & \multirow{4}{*}{$\begin{array}{l}\text { Renewable energy } \\
\text { supply }\end{array}$} & Austin & USA & In-house & \\
\hline & & Melbourne & Australia & $\begin{array}{l}\text { Procuremen } \\
\mathrm{t}\end{array}$ & Supply and install \\
\hline & & Rizhao & China & Public & Regulation, subsidy \\
\hline & & Barcelona & Spain & Public & Regulation \\
\hline & \multirow{3}{*}{ Energy savings } & Chicago & USA & In-house & \\
\hline & & Copenhagen & Denmark & In-house & \\
\hline & & Tokyo & Japan & Public & Regulation \\
\hline & Street lighting & Los Angeles & USA & In-house & \\
\hline \multirow{4}{*}{ Building } & \multirow{4}{*}{ Energy savings } & Berlin & Germany & PPP & ESP \\
\hline & & London & UK & PPP & EPC \\
\hline & & Stuttgart & Germany & In-house & \\
\hline & & Paris & France & PPP & $\mathrm{PFI}^{3}$ \\
\hline $\begin{array}{l}\text { Urban } \\
\text { development }\end{array}$ & & Dongguan & China & PPP & \\
\hline \multirow{3}{*}{ Waste } & \multirow{3}{*}{$\begin{array}{l}\text { Waste } \\
\text { management }\end{array}$} & Gothenburg & Sweden & PPP & Management contract \\
\hline & & Sydney & Australia & PPP & $\mathrm{BOO}$ \\
\hline & & Dhaka & India & NGO & \\
\hline \multirow{3}{*}{ Water } & \multirow{3}{*}{ Water distribution } & Tokyo & Japan & In-house & \\
\hline & & Emefuloni & $\begin{array}{l}\text { South } \\
\text { Africa }\end{array}$ & PPP & BOT \\
\hline & & Austin & USA & Public & Regulation, subsidy \\
\hline
\end{tabular}




\section{Box 3. The Eco-Stadium of the City of Nice}

The City of Nice Eco-Stadium project illustrates the potential of a global contract and the necessary conditions for PPPs to reach this potential. The project - including design, financing, construction, operation, and maintenance aimed to build a stadium with a positive energetic balance sheet. Designed as part of a proactive sustainable development program, the stadium includes an exceptionally large-scale wood structure and a unique arrangement of natural air-conditioning (a fan wall system cools the stadium using prevailing winds).

This type of innovative project would have been difficult, if not impossible to develop under traditional procurement. As the leader of the entire project from design to maintenance over a 30 -year contract, the private operator has a high incentive to innovate - even at the cost of higher up-front investments - in order to reduce the cost of the project overall. Furthermore, the operator must be accountable for objective targets and measures. For example, in this project, an assessment of the energy production and cost of the stadium and its parking lots, shops and museum determines the operator's commitments.

There are two types of green PPP projects: greenfield projects and brownfield projects. In brownfield projects, the private sector participates (as investors and operators) in existing infrastructure facilities; greenfield projects develop new infrastructure, such as a new wastewater treatment facility. While both greenfield and brownfield PPPs can have environmentally friendly characteristics, it is easier to make greenfield PPPs truly green. In the building sector, for example, the recast of the 2002 Energy Performance of Buildings Directive (EPBD) - adopted by the European Parliament and the Council of the European Union on 19 May 2010 - strengthens the energy performance requirements of both new and existing buildings across the European Union (EU). For new buildings, the recast fixes 2020 as the deadline for all new buildings to be "nearly zero-energy buildings" $"$ (and even sooner - by the end of 2018 - for public buildings). For existing buildings, member states must draw up national plans to increase the number of nearly zero-energy buildings (though no specific targets have been set).

One of the most innovative urban green PPPs is Energy Performance Contracting (EPC). The EU Directive 2006/32/EC, which lays the legal foundation for such contracts in the EU, defines EPC as "a contractual arrangement between the beneficiary and the provider (usually an Energy Service Company - ESCO) of an energy efficiency improvement measure, where investments in that measure are paid for in relation to a contractually agreed level of energy efficiency improvement". The objective of EPC is not the execution of works (supply of goods or services), but the improvement of energy efficiency (i.e. reduction of energy consumption) (Box 4). This is an innovative approach to contract design and thus raises specific issues related to performance measures and verifiability under the context of legal and technological uncertainty. The use of a performance-oriented contract is only possible when energy efficiency is perfectly measurable, with observable and verifiable indicators. Depending on the sector and the objectives of a given project, such measure may be difficult to establish and contest. The more difficult the control, the more likely ex post conflicts concerning efficiency targets, observed performances and responsibilities will occur. These conflicts are costly and affect the efficiency of PFI. 


\section{Box 4. Energy performance contracting}

Despite the definition given by the EU Directive 2006/32/EC, the definition and implementation conditions of energy performance contracting (EPC) vary in different countries. This affects how EPC is marketed (i.e. high or low market visibility) as well as the cost and quality of services provided by suppliers. Still, there are common features of EPC:

- $\quad$ EPC is objective-oriented, in that a private contractor's revenue under EPC depends at least partly on energy savings that have been achieved. The cost of investment (in air conditioning systems, energy management control systems, efficient lighting, peak load management, thermal insulation as well as campaigns to make users sensitive to energy savings) is paid back from the energy savings. If the Energy Services Company (ESCO) fails to achieve the estimated energy savings, they must cover the difference between the invested cost and the realised savings. In addition, to ensure that the building is used in the most efficient way, building occupants receive training on energy efficiency practices. Since EPC is a performance contract, rigorous procedures for assessment and verification performance have to be implemented by ESCOs. EPC is thus an incentive contract that should improve energy efficiency.

- $\quad$ EPC is a global contract, for which the ESCO designs, realises, exploits, and maintains energy-saving equipment, supporting most of the performance risks.

- $\quad$ EPC is a long-term contractual agreement, through which the customers should benefit from new or upgraded energy equipment along the life of the contract.

Urban green PPPs might face challenges if their objectives result in decreased consumption. Such objectives appear incompatible with concession contracts, in which the gains of the private operator is positively linked to the level of consumption. The greening of public services through concession-type contracts is thus problematic. The frequent use of concession-type contracts for water utility contracts in France illustrates this problem: when private operators' payment is based on the amount of water consumed, conserving natural resources (i.e. reducing the quantity of distributed water) conflicts with increasing earnings (Box 5).

\section{Box 5. Are concession contracts adapted for water services?}

The private sector provides water services to $75 \%$ of the population in France. France is one of the three countries worldwide (other two being Chile and the United Kingdom) with the highest share of private sector provision in this sector. The French debate about water concession contracts; the re-municipalisation of water services (e.g. in Paris) is largely connected to the misalignment of contractual tools. Some municipalities would like to focus on reaching environmental targets, like reduced water losses, improved resource protection and reduced consumption. However, the contracts that allow municipalities to partner with private operators through a global contract are concession or lease contracts, both of which base payment to operators on the volume of water consumed. This clearly contradicts the willingness to achieve water consumption reductions. A new paradigm is therefore necessary, and there are many options. Concession and lease contracts could be replaced with PFIs, in which operators are paid through their capacity to reach quality targets (e.g. volume reduction of water consumption). Mixed payments provide another alternative: consumers pay for water services, while citizens' taxes cover costs of other services that benefit the whole society (e.g. resource protection, leakage reduction). Thus, a continuum of PPPs is possible, with a mix of features of concessions and PFIs.

Green projects face high uncertainty regarding technological and legal developments. In most standardised PPPs, project technologies are built-in or traditional, and market-tested throughout the long-term and repeated government procurement processes. However, some green technologies, including resource recirculation or renewable energy technology, are new and less verified in the field. Sometimes, they need to be modified to meet new criteria of the environment or energy saving index. 
New technologies are less likely to be accepted to project developers or financial investors, since they are more vulnerable to various risks of technology failures. Limited experience with and evidence on green PPPs to properly guide optimal concession designs increases the level of uncertainty in the processes of project design, implementation, financing, and operation and maintenance. For this reason, cities like Amsterdam (Box 6) have introduced forms of co-operation that aim to promote knowledge exchange between the different actors involved in green finance.

\section{Box 6. Green Finance Lab in Amsterdam}

The Green Finance Lab is an initiative of the City of Amsterdam and the Dutch bank ABN AMRO, as part of the Amsterdam Sustainability Programme and a Green Deal between the City of Amsterdam and the Dutch national government. The Green Finance Lab aims to find new financing mechanisms for realising the transition towards a sustainable metropole (including ecosystem services, energy, water, raw materials and transportation). The Lab serves as a forum for stakeholders from different sectors (public, private, NGO and research) to develop new financial solutions for sustainability challenges. In 2011, the first Lab focused on the financing of green areas around Amsterdam, followed in 2012 by the organisation of "chambers" for sponsorship, donations, private investment zones and value capture finance. Each chamber brings together entrepreneurs (from the private, social or public sector) and investors. These entrepreneurs frame their proposals in parameters that give maximum information to investors (e.g. cash flow, risk management), while investors comment, coach and help search for innovative solutions where conventional mechanisms fall short.

This uncertainty makes for a complex trade-off between flexibility and rigidity of the contract. The more a contract is complete, the more likely costly renegotiations can be avoided. However, completeness also means rigidness; and in a complex and uncertain environment, contracts need flexibility rather than rigidity: the more the contract is incomplete, the more it is flexible and adaptable to unanticipated contingencies and open to incorporating new incentives for cooperative behaviour. Still, it does not protect against opportunistic behaviours from the public body or the private partner. The often-high uncertainty of green projects thus increases the need for flexibility and, as a consequence, the insecurity and instability of PPP relationships under permanent threat of opportunism.

PPPs may sometimes be too rigid in the context of technological evolution: if PPPs cannot easily incorporate technological innovation during the life of the contract, they lose their comparative advantage to internal public solutions and traditional procurement. Thus, PPPs may not always be a good candidate for green projects with strong technological components. Some national governments (e.g. South Korea) put packages in place to stimulate urban green infrastructure PPPs by taking away some of the risks connected to this uncertainty (Box 7).

\section{Box 7. National incentives to stimulate green infrastructure PPPs: The case of South Korea}

The national government of South Korea promulgates various kinds of financial and tax incentive policies that can facilitate green infrastructure PPP financing, in line with its First Five-Year Action Plan for Green Growth, initiated in 2009. More specifically, the government provides (i) construction subsidies, (ii) compensation for base cost, (iii) infrastructure credit guarantees via the Infrastructure Credit Guarantee Fund, and (iv) tax incentives.

i. Construction subsidies: According to the PPP Act, the government may grant a construction subsidy to the concessionaire, if it is required to maintain the user fee at an affordable level. The timing of the subsidy is determined in the course of the concession agreement and depends on the equity investment plan of the concessionaire. The timing of the distribution reflects the completion level of the project and the schedule and scope of equity investment. The amount of subsidy is determined in each individual 


\begin{tabular}{|c|c|}
\hline & $\begin{array}{l}\text { concession agreement. When notifying about a project, the government first discloses an approximate } \\
\text { ratio of the construction cost that it is willing to subsidise. The exact ratio of subsidy to construction cost } \\
\text { is determined through consultation and is stipulated in the concession agreement. As a result, each } \\
\text { project ends up with a different amount of subsidy. The government has set a subsidy guideline for road } \\
\text { projects of } 20 \%-30 \% \text { of the total project cost. It has set a subsidy guideline for railway projects of up to } \\
50 \% \text { of total project cost. The ratio of subsidy to construction cost for environmental projects is } \\
\text { stipulated by law (50\% to } 80 \% \text { ) and included in the government's public notification. Generally speaking, } \\
\text { more green-oriented projects are eligible for larger subsidies than the other projects. }\end{array}$ \\
\hline ii. & $\begin{array}{l}\text { Compensation for base cost: the government assumes a portion of investment risk. This risk is limited to } \\
\text { what the government's costs would have been in the case of a public-financed project. The government } \\
\text { payment is made for the amount of shortfall in the actual operational revenue compared to the share of } \\
\text { investment risks by the government. }{ }^{7} \text { When the actual operational revenue exceeds the share of } \\
\text { investment risks, government subsidies are redeemed on the basis of and within the limit of the amount } \\
\text { previously paid. On the part of the private participant, subsidies are provided only when the actual } \\
\text { operational revenue surpasses } 50 \% \text { of investment risk. }\end{array}$ \\
\hline iii. & $\begin{array}{l}\text { Infrastructure credit guarantee fund (ICGF): Since 1994, the ICGF has provided credit guarantees to } \\
\text { concessionaires who want to obtain loans from financial institutions for PPP projects. According to the } \\
\text { PPP Act, the ICGF is managed by the Korea Credit Guarantee Fund. The ICGF consists of annual } \\
\text { government subsidies, guarantee fees and investment returns. When the project guaranteed by the } \\
\text { ICGF defaults, the ICGF subrogates on behalf of the project company. Additional government } \\
\text { contribution can be granted if the funds are insufficient. The limit of the credit guarantee per } \\
\text { concessionaire is KRW } 100 \text { billion, but in cases where the director of the management institution } \\
\text { considers it necessary, the limit may be raised to KRW } 200 \text { billion. The guarantee fee will have a } \\
\text { maximum annual fee rate of } 1.5 \% \text {. }\end{array}$ \\
\hline iv. & $\begin{array}{l}\text { Tax incentives: To facilitate infrastructure financing, the government provides tax incentives that are } \\
\text { stipulated in the PPP Act. Details of the tax incentives are also included in the PPP Basic Plan in four } \\
\text { categories: special taxation, corporate tax, local tax and exceptions from charges. The PPP Act directs } \\
\text { the government to enact special taxation for infrastructure bond, value-added tax, foreign investment } \\
\text { zone, and infrastructure fund. A separate taxation rate of } 14 \% \text { is applied to the interest revenue from } \\
\text { infrastructure bonds. A } 0 \% \text { tax rate is applied for the value-added tax for infrastructure facilities or } \\
\text { construction services. Reduction of and exemption from taxes, including corporate tax, income tax, } \\
\text { acquisition tax, registration tax, and property tax, are applied to foreign investment in the foreign } \\
\text { investment zone. With respect to the dividend income distributed for the infrastructure fund, a } 5 \% \text { tax } \\
\text { rate is applied to the dividend income from the equity investment portion up to KRW } 300 \text { million and a } \\
14 \% \text { tax rate is applied to the dividend income from the equity investment portion exceeding KRW } 300 \\
\text { million. Local tax exemptions for PPP projects, which include an exception for three times the } \\
\text { registration tax within the capital region and an exemption from acquisition and registration tax are } \\
\text { included as well. }\end{array}$ \\
\hline
\end{tabular}




\section{Conditions for success}

PPPs may help increase public awareness and expand the diversity of stakeholders in green city development. Creating a favourable environment for private sector participation by strengthening cash flow from concessional loans and grants may contribute directly to the establishment of new green projects, resulting in the realisation of projects that could not be pursued with traditional government procurement alone. Private firms not only can foster corporate social responsibility by participating in green projects, but also can create markets for green products by facilitating a better investment environment. Although most green projects are highly uncertain, PPP diversifies business risks and stakeholders by promoting joint public-private activities. It enables the implementation of large infrastructure projects too costly for either the public or private sector to pursue on its own. Because all participating agencies make joint contributions to increasing resources by collaborating with the private sector, more green projects can take advantage of government subsidies and public funds, with risks distributed more evenly among the participants.

Competition and expertise within the private sector can enhance efficiency and effectiveness of green public investment under PPP. Since PPP enables the efficient undertaking and operation of large projects related to the green economy throughout competitive bidding and concession contracting processes, it has been adopted to support projects more amenable to private sector participation. The public and private sectors have been cooperating in a wide range of areas based on the accumulation of experience by the private sector in green investment. The PPP is expected to improve the conditions for businesses' entry into the market and facilitate capacity building. Enhancement of efficiency and effectiveness, however, requires well-designed, well-implemented concessions and related government regulations, and depends on several conditions.

- Effective partnerships are crucial to the success of green urban PPPs. Unlike traditional procurements for assets or services, which use shorter-term contracts to acquire or renovate public assets, a green PPP is a global contract, which may last for 15 to sometimes more than 90 years. Establishing a real partnership based on co-operation, expertise and credible commitment is essential and requires a different approach than shorter contracts. Especially for complex green PPPs, the public body must also acquire internal knowledge and expertise necessary to define the terms of the agreement.

- Interaction and negotiation with one or several operators during the call for bidders phase could clarify the objectives of the partnership and provide innovative technological solutions not yet envisioned by the public body. This interaction in the bidding phase is especially helpful for green PPPs negotiated in an uncertain environment with complex technologies that vary in speed of obsolescence. In order for this phase to be efficient, the public body must invest in gaining enough expertise and generating sufficient competition to challenge private partner candidates.

- Clear environmental objectives and their weight in the procedure to award PPP-projects must drive effective green PPPs. The addition of green requirements to the project specification after PPP design will be costly and likely problematic (i.e. incompatible with technological choices put in place). In addition, environmental targets must be measurable and clearly defined, with agreed upon approaches for ex post monitoring explicitly described in the contract. Since most of these methods and protocols evolve over time (due to both innovation and demand evolution), they should also be adaptable. 
- $\quad$ Flexibility is a key element of green PPPs. Discussion with private operators for a green PPP should focus on efficient and flexible solutions that allow for speedy response to changing requirements and new technologies. This is an option-value trade-off that might increase costs. In addition, the contract should describe and anticipate how the relationships evolve over time as soon as unanticipated events occur (e.g. what renegotiation procedures, what termination procedure).

Instead of introducing green aspects in PPPs, PPPs could be designed so that operators are paid solely on their ability to reach environmental targets. In many cases, this will not be possible because it would lead to risk transfers that would be considered too high by the operator. When feasible, this arrangement would send a clear signal about the willingness of the city to favour green aspects in bid selection. The private operator would also be more incentivised to take green commitment seriously. In this case, the selection of the best candidate should be based not on one single criterion (e.g. price), but on the economically most advantageous criteria such as whole life costs, quality, deliverability, flexibility, innovation and level of risk transfer. However, given higher costs, the real willingness and capacity of cities to enter this game remains in question.

\subsection{Stimulating private investment: The case of tax increment financing (TIF)}

Tax increment financing (TIF) is an economic development tool used to encourage the redevelopment of areas in need of revitalisation and brownfield remediation. ${ }^{9}$ Cities designate a TIF area for capital improvements and then earmark any future growth in property taxes to pay for investments in infrastructure and other economic development initiatives. TIF districts are often the beneficiaries of federal and state grants and tax incentives, and these additional funds help to achieve the revitalisation objective (Box 8). TIFs were first introduced in California in 1952 and since then have spread to almost all US states. ${ }^{10}$ In Chicago, by $2005,10 \%$ of all property taxes were earmarked for TIF purposes, and TIF districts covered more than 25\% of the city's geographic area (Quigley, 2007). In Canada, TIFs are a much newer instrument and not nearly as widespread as in the US. TIF legislation was passed in Manitoba in 2008, but the instruments are not yet being used in that province. In Alberta, TIFs are known as community revitalisation levies (CRL) and are being used in Calgary and Edmonton. In Ontario, TIFs are being considered for two pilot projects in Toronto, pending the passage of enabling regulations. ${ }^{11}$

In recent years, however, the underlying purpose of TIFs and their impact on green infrastructure have come into question. ${ }^{12}$ TIFs were originally designed as a tool to stimulate private investment in urban cores and to assist these areas to compete with outlying suburban and exurban areas. The rationale behind TIF districts is that revitalisation can have a positive impact on urban quality of life and future tax revenue. However, as one author notes, TIFs are "a complicated device for subsidising development that has morphed from a tool for inner-city revitalisation into a widely used suburban program frequently associated with disputes about sprawl" (LeRoy, 2008, 3). 


\section{Box 8. How does tax increment financing work?}

Cities designate a tax increment financing (TIF) district for capital improvements and then earmark any future growth in property taxes to pay for investments in infrastructure and other economic development initiatives. TIFs are governed by state/provincial legislation and are thus applied differently in different states and provinces. They do, however, follow a similar approach:

- Initially, a TIF district is proposed based on planning criteria and what is permitted in the enabling legislation. The geographic boundaries of the TIF district should reflect the area in need of redevelopment. Public consultation is held and a redevelopment plan is developed for the district.

- Once the area has been given official status, the annual property tax revenue accruing to all taxing authorities within the district (the municipality, the county, school boards, etc.) is frozen at pre-revitalisation levels. ${ }^{13}$ These property taxes are known as "base level" taxes. For a period between 15 and 35 years, all or some portion of the incremental tax generated (above the base level) accrues to the redevelopment agency (or the municipality) to be used for the redevelopment.

- To kick-start the redevelopment, the municipality or redevelopment agency invests in infrastructure and/or acquires land. TIFs are generally used to cover the cost of studies, surveys and plans; professional service costs such as architectural, legal and engineering; property assembly costs, including land acquisition, demolitio, and land clearing; costs of rehabilitation, reconstruction, repair or remodelling existing buildings and fixtures; costs of construction of public works or improvements; financing costs; capital costs resulting from the redevelopment project; and relocation costs. Generally, TIFs cannot be used to pay for general government operations including police and fire protection, road maintenance or similar operating costs, or for the construction or financing of government buildings. In some US states, TIFs are even used to offset private development expenses such as site preparation and construction.

- Capital investments are usually funded through borrowing or issuing bonds against the expected incremental tax increases (TIF bonds). TIF funds are used to pay back these bonds.

- $\quad$ After the TIF period expires, tax revenues from the expanded assessment base again flow through to the taxing authorities.

TIFs are not the same as tax abatements. Under a TIF, the development is financed from increases in tax revenue generated by the development and not from a municipal subsidy. There is no transfer of funds from the municipality to businesses, nor is there a transfer from one business to another. Taxes from the increase in the assessment base are used to finance public improvements in the district. The widespread use of TIFs in the US is, in part, because they offer a way for municipalities to get around borrowing limits; tax increment bonds are not subject to municipal debt limits or public referendum requirements in most states. This financing method results in more capital for infrastructure than would otherwise be available with traditional general obligation bonds.

The designation of a TIF district usually requires that an area be "blighted" and that the development would not take place "but for" the incentive. Over time, however, both of these requirements have been relaxed in many US states, calling into question the extent to which they promote green infrastructure. In terms of blight, TIF legislation in some states sets out specific conditions such as overcrowding, dilapidated or deteriorating buildings. Other states, however, lack any legal definition of "blight". 14 The requirement that the area be blighted has been essentially ignored (Youngman, 2011), as TIF districts can be created in any neighbourhood. A 1999 study suggested that $45 \%$ of Wisconsin's 661 TIFs were used to develop open space, mainly farmland, including a superstore on what had previously been an apple orchard. Other applications of TIFs include a golf course project on Greenfield in Des Moines, Iowa to pay for sewer lines and a shopping mall in St. Louis, Missouri (LeRoy, 2008).

In an era of fiscal restraint and declining federal and state grants, municipalities are looking for new ways to raise revenues. As a consequence, instead of using TIFs in blighted neighbourhoods where they are most needed, they are often used where they can bring in the most revenue. 
Municipalities are anxious to extend TIFs to more affluent neighbourhoods because blighted areas have the least chance of increasing property values sufficiently to pay back TIF bonds. Furthermore, TIFs are more likely to be successful on undeveloped land, such as agricultural land that is eligible for preferential farmland programs (Youngman, 2011). Farm properties offer the greatest potential for property value increases not only because they are undeveloped, but also because they would be reclassified from farmland (levied at a low tax rate) to commercial or industrial properties (levied at a high tax rate). However, as one author notes, "the use of TIF for large-scale greenfield projects - of whatever quality - seems far afield from both the original mission of TIFs and the intent of smart growth" (LeRoy, 2008, 10).

TIFs can only be used for expenditures that meet the "but for" test. This test ensures that the development would not have taken place "but for" (without) these expenditures. Typically, the expenditures that meet this test are those that put infrastructure in place for the development or reduce the risk to developers so that they are willing to undertake the development. The "but for" test, like the determination of what is a blighted neighbourhood, has been compromised and, as LeRoy (2008) and Youngman (2011) argue, has become merely a gesture of formality to justify that TIFs are not simply giveaways to developments that would have occurred anyway.

\subsection{Making the developer pay: Development charges and value capture}

Several cities earn much of their revenues through land sales to developers. This can create incentives for urban sprawl, as shown by the metropolitan cities in China's Guangdong province. The contribution of land sales to local revenue was estimated to be 55\% in the City of Guangzhou in 2006 and about $80 \%$ in the City of Shenzhen throughout the 1990s (Tian and Ma, 2009; Peterson, 2006; OECD, 2010c). Although these could be valuable instruments to capture land value increases and to finance infrastructure, in practice local governments in China have been so motivated to generate revenues from land sale and leasing that they have generated an oversupply of land for construction. This has stimulated sprawled development and loss of cultivated land in the whole of China. Similar dynamics, though less extreme, are evident in other metropolitan regions in the OECD. Municipalities in the peri-urban fringe of many German agglomerations compete with each other by developing new land to attract inhabitants and companies, thereby producing revenue used to finance public services. This dynamic is made possible by municipal autonomy in land-use planning and large demand for undeveloped land; the result is an undermining of sustainable planning principles.

\section{Charging project developers}

Cities throughout the OECD try to make developers pay for the infrastructure costs of new development and related sprawl. Municipalities across North America levy development charges or impact fees to pay for infrastructure in new developments. ${ }^{15}$ A development charge is a one-time levy on developers to finance the growth-related capital costs associated with new development or, in some cases, redevelopment. These charges are levied for works constructed by the municipality, and the funds collected must finance the infrastructure needed for the development. Development charges are appropriate for financing infrastructure in areas experiencing new growth but not applicable to maintenance and replacement of old services.

Historically, municipalities have required developers to provide or pay for on-site services, such as streets, street lighting, sidewalks and other public facilities within the subdivision. Subdivision agreements between the municipality and developer require the developer to take responsibility for providing (or funding) these services to meet municipal specifications as a condition of subdivision 
approval. Over the last 30 years, municipalities have extended the responsibility to developers to pay for the off-site costs associated with new development. These growth-related costs have traditionally included "hard" costs for roads, water and sewage systems and, in some jurisdictions, also "soft" costs for services like libraries, recreation centres and schools. The rationale for charging developers for offsite growth-related costs is that "growth should pay for itself" and not be a burden on existing taxpayers (Slack, 2002). ${ }^{16}$

Several studies investigating who ultimately pays the development charge conclude that bearer of the burden - the new homebuyer, developers or pre-development landowners - depends to a large extent on the demand and supply conditions in the market for new housing (Slack and Bird, 1991). Most studies conclude that, over the long-term, development charges are borne by the new homebuyer. In some cases, the predevelopment landowner, or some combination of the homebuyer, predevelopment landowner and the developer, may bear the cost. To the extent that the new homebuyer bears the cost, the beneficiaries of the infrastructure pay for it.

If properly implemented, development charges can take into account the externalities of new urban development and discourage urban sprawl. In order to have this effect, the charges have to be differentiated by location to reflect the different infrastructure costs. For example, costs tend to be higher for developments located further away from major facilities and for low-density developments. To be efficient, development charges would be higher in these locations. Area-specific charges allow municipalities to vary the charge according to the different infrastructure costs imposed by each area on the city.

The costs of services may vary by location for at least three reasons (Tomalty and Skaburskis, 1997). First, the distance of each development from major facilities makes a difference. A development far away from an existing water treatment plant, for example, may require an additional pumping station. Second, there will be infrastructure cost savings for nodal or infill development because the infrastructure is already there. Third, service standards may vary in different developments (e.g. household water use versus waste generation). Whatever the reason for the differential costs, efficient land use requires that developments imposing higher infrastructure costs on the city pay higher development charges than developments imposing lower costs. Pamela Blais (2010) notes that, in addition to varying by location, charges should also differ according to the density and type of development to avoid low-cost areas subsidising high-cost areas, small lots subsidising large lots, and smaller residential units subsidising larger units.

Development charges that reflect the true cost of providing services can buttress planning tools by guiding development away from high-cost areas to more efficient locations (Tomalty and Skaburskis, 2003). As Skaburskis $(2003,197)$ notes, pricing policies can be an effective planning tool because "they directly engage developers, they make them accept the full project costs, they recognise and publicise the need to correct for the external costs of development by increasing the cost of land, and they raise funds for infrastructure development and compensation programmes." When urban form and density are not fully factored into the development charge, a market distortion occurs and inefficient allocation of resources often results (GTA Task Force, 1996, 128). A uniform charge subsidises inefficient uses of land; developments that impose higher costs are subsidised by developments that incur lower costs. In practice, several applications do not foster green development:

- Canadian municipalities are not using development charges as a financial instrument to discourage inefficient and costly land uses (Tomalty and Skaburskis, 2003). Most municipalities impose the same charge on all properties of a particular type regardless of location. In Ontario, for example, few municipalities differentiate development charges by location with the exception of municipalities in the York Region. Presumably, the practice of 
uniform charges has been adopted for administrative simplicity and perhaps also for reduced conflict with developers (OECD, 2010a, 172), but it is clearly inefficient. One result is likely to be over-development of low-density housing and under-development of high-density housing relative to what is economically efficient (Slack, 2002). In British Columbia, however, area-specific development charges are more common. ${ }^{17}$ The provincial government's Development Cost Charge Best Practices Guide suggests that development charges be varied according to density to encourage more compact development and reduce the amount of roads needed, increase the viability of transit and leave a smaller ecological footprint (British Columbia Ministry of Community Services, 2005).

- In US jurisdictions, impact fees are widely used but their design is generally not consistent with efficient pricing of infrastructure (McGuire and Sjoquist, 2003). The reason is that fees are generally based on average costs rather than marginal costs. This means that fees are the same for an infill development close to existing services and a greenfield development on the outskirts of a city. Communities generally use one of two methods for calculating impact fees on single-family homes: a uniform charge regardless of size or a sliding scale that responds to either interior square footage or the number of bedrooms (Burge, 2010).

Other problems can arise from the way in which the charge is determined. In Ontario, for example, municipalities are only permitted to charge the infrastructure costs for services that are already delivered in the municipality and only for standards of service that do not exceed the average level of service over the previous ten years. If a municipality chooses to encourage compact development by increasing transit service, for example, the development charge cannot be used to cover costs that exceed the existing standard. Although these provisions were instituted to ensure that developers are not responsible to pay for gold-plated services (services that exceed what existing residents currently enjoy), they make it difficult for municipalities to recover transit costs (OECD, 2010a).

\section{Capturing value connected to infrastructure investment}

Smart land-based instruments can simultaneously increase both urban revenues (brought in by developers) and urban density. In São Paolo, for example, building rights for additional floor space on top of existing buildings, exceeding normal maximal density, were sold in locations authorised for higher-density development (Box 9). Through a similar mechanism in the state of Maharashtra, India, the maximum floor space index (FSI) was increased, with the extra FSI sold to developers. Both schemes, particularly relevant for growing cities with a scarcity of land, have generated additional infrastructure funding while increasing urban density. Developers can also pay for sustainable transport infrastructure by capturing the value increases resulting from new public infrastructure investment. Countries have had mixed success with this method: Singapore, for example, has made ample use of such instruments to finance infrastructure, but Poland has experienced difficulties implementing similar instruments (Box 10).

Urban green infrastructure could also be financed by local businesses, for example via business improvement districts (BIDs). Originally invented in Ontario, Canada, BIDs are widely used in the US and Europe since the 1960s. This mechanism facilitates financing and managing improvements to commercial and industrial environments based on the agreement by a majority of businesses (either land owners or tenants) who accept an additional levy. Once a district is established, revenue is available through long-term debt for capital investment. Initially, BID resources often support additional safety and sanitation services, but they can develop into much more sophisticated investments and initiatives such as joint promotional initiatives. The district governing board, usually consisting of city government representatives and private business representatives, avails itself to a 
host of financing methods for district improvement. The boundaries of such districts are usually a contiguous commercial or industrial area within a central city location, though they can also be effectively used in suburban and ex-urban industrial locations. In cases of multiplicity of fragmented jurisdictions at the local level, coupled with multiple tax rates and fiscal system, BIDs have become an attractive new addition to local fiscal and management instruments. BIDs are only workable with a critical mass of businesses willing to pay for particular services. They are also good tools for tightly bound, reasonably healthy commercial and industrial centres that are densely populated by the owners/users. However, BIDs are less effective in areas that are more spread out or have a high degree of mixed land use, where it is harder for the payer to capture the benefits of targeted improvements in services.

\section{Box 9. Selling building rights in São Paulo, Brazil}

The São Paulo Municipality in Brazil has successfully used new financial instruments to generate resources for urban regeneration and infrastructure investment in various parts of the city. The municipality has sold building rights exceeding USD 1.2 billion in the last six years in two "Urban Operations" projects based on the sale of additional floor space. The municipality changed land-use occupation regulations concerning floor area ratio (FAR) in relation to these projects. The total available stock of new building rights made available through this programme may be used for the transfer of individual lots or virtually, through property certificates of built area called Special Additional Potential Construction Certificates (Certificados de Potencial Adicional de Construção, or CEPACs). CEPACs are issued by the city and purchased by individuals who link them to their plot of land, thus increasing the total FAR permitted. These securities are issued by the municipality, and the funds are transferred to the Treasury, where they remain in a fiduciary account. CEPACs are issued and traded in the São Paulo Stock Exchange, which requires intermediation from a financial institution such as Banco do Brasil. However, the financial institutions give no guarantees. The CEPACs are intended to create reserves for carrying out public works, such as subway extensions, which aim to increase mobility and improve infrastructure under the city's master plan. Though property values around the area typically increase, the Urban Operations are intended to encourage mixed use and increase the space available for residential and commercial development, thus creating value for the real estate market.

Different conversion rates of CEPACs into building areas allow city planners further discretion over incentives for specific sub-areas in the same Urban Operation. For example, if a conversion rate in a sub-area is set for two, it will cost half as much to buy an additional square metre than in a sub-area where the conversion rate is one. City planners can then incorporate relative market prices for different sub-areas in order to set conversion rates that will encourage development in that sub-area. Different conversion rates for commercial or residential use can also encourage development in the desired use and in mixed-use development.

The municipal law that creates each Urban Operation designates SP-Urbanismo (a public company linked to the Urban Development Secretary developing the Urban Operation Master Plan) as responsible for managing the process, controlling the finances and supervising contractors for the construction. The law also encourages community participation by stipulating that members of civil society be represented on managerial committees.

Source: Fróes, M. and J. Rebelo (2006), “Urban Operations and the São Paulo Metro Line 4”, Working paper, The World Bank. 


\section{Box 10. Betterment levies in Poland}

Poland is one of the few OECD countries with a betterment-capture mechanism intended to capture windfalls due to planning decisions. The levy is assessed through a parcel-by-parcel appraisal, in order to determine the real value increase attributable to a new or revised plan. The municipalities administer the levy and keep its revenues. Another financial instrument using land values in Poland has been the "adjacency levy", based on the market value increase of land resulting from the installation of local public infrastructure (e.g. roads, sewers, water supply and other utilities) adjacent to newly installed municipal infrastructure. The law permits local authorities to set levy rates up to $50 \%$ of project costs. A majority of local governments have adopted the levy.

In practice, assessing the incremental land value created by local plans or public improvements, such as new infrastructure provision, proved to be very difficult. Special appraisers were hired to estimate before-and-after land values, parcel by parcel, within improvement districts designated by the local government. However, the Supreme Administrative Court set aside many of the appraisers' decisions, finding wrongful determination of land-value gains. Administrative costs were high, running as much as $30 \%$ of revenue collections. A case study of Szczecin, a city in the north-west of Poland with approximately 400000 inhabitants, found that only 26 land parcels were assessed for landvalue gains and that the total amount of revenue collected was equal to $0.6 \%$ of public infrastructure investment in the areas designated as improvement districts. The betterment statute was annulled after less than a year, primarily because the controversy over land-value determination outweighed the revenue generated (Gdesz, 2005).

The disappointment over the betterment levies in Poland reflects a tendency worldwide to abandon parcel-byparcel betterment levies. Countries that continue to use some sort of betterment levy, such as Colombia, have transformed it from parcel-by-parcel estimates of land value gains into a citywide bundle of public works projects, financed in part through a citywide fee, broadly differentiated by benefit zone and other factors (Peterson, 2009).

\subsection{Loans, bonds and carbon finance}

Larger access to loans and bonds could help to mobilise finance for green urban investment. Bonds provide institutional investors, such as pension funds, stable yields and limited risks. Urban green infrastructure investments currently use both to a limited extent, but they could be leveraged more often for infrastructure investments (Della Croce et al., 2011). There is a relationship between access to borrowing and cities' own revenue sources: the more revenue sources a city has, the higher its perceived repayment capacity, and thus the greater its access to debt markets, including loans.

Local government access to private loans could increase as long as sound local financial management practices are in place. Some OECD member states' fiscal rules may ban local governments from borrowing or issuing bonds; while others constrain the size of municipal budget deficits or debt levels. In most OECD countries, local governments are only allowed to borrow to finance investment (the golden rule for debt financing). In some countries, only long-term borrowing is limited to investment, while short-term loans may be used to finance operating expenditures. Local borrowing is also subject to prudential regulations, based on debt service and repayment capacity. In most countries, collateral restrictions exist for debt issuance. As a result of all these constraints, local governments generally have a low debt to GDP ratio; only in a few OECD countries (e.g. Denmark, Iceland, Italy and the Netherlands) does the stock of local government liabilities reach $10 \%$ of GDP or more. However, sound local financial management practices could limit the risk of perceived subnational fiscal irresponsibility that underlies many of the constraints on sub-national access to borrowing. 


\section{Elaborating green bonds}

Green bonds are promising vehicles for cities to attract private finance. Green bonds provide a channel for directing institutional investor capital towards green projects (Della Croce et al. 2011). Institutional investors, such as pension funds, invest in infrastructure. For example, the Ontario Teachers' Pension Plan owns a subsidiary that runs container port terminals in Vancouver and New York/New Jersey; and other Canadian pension funds are not only funding but actually also running toll roads in major cities in Australia and the US. Institutional investors in OECD member countries seek long-term investments with steady yields and limited risks; their portfolios are thus dominated by bonds, accounting for half of total assets under management in OECD pension funds. The share of bond investment in green infrastructure is currently small, and even smaller for green urban infrastructure, but three promising models exist:

1. Multinational development banks: Multilateral development banks have started to fund green bonds. To ensure returns, the World Bank's green bonds were structured with standard financial features, such as an AAA credit rating. Urban green investment projects are estimated to make up $20 \%$ to $25 \%$ of the green bond portfolio. ${ }^{18}$ Other development banks have created similar instruments: the European Investment Bank has developed Climate Awareness Bonds financing green projects in several cities, such as district heating in Paris.

2. US Green Bonds: Unlike many other countries, the US has a well-developed market of taxexempt local bonds that can substantially help finance cities. These include Clean Energy Renewable Bonds (CREBs), Qualified Energy Conservation Bonds (QECBs), Property Assessed Clean Energy Bonds (PACE) and Build America Bonds (BABs) (see Della Croce et al., 2011). Some cities, including Chicago, have developed their own green bond programme for energy efficiency and renewable energy goals. Such programmes, however, are only viable for cities that have credit ratings similar to the national credit ratings; if not, a national programme would make more sense.

3. Climate-specific institutional investors groups: Several institutional investors have grouped together to form climate change groups (e.g. Institutional Investors Group on Climate Change [IIGCC] and the Investor Network on Climate Risk). They are creating their own financing packages, such as climate bonds, and could potentially be interested in urban sustainability projects.

\section{Box 11. What are green bonds?}

Green bonds are fixed-income securities issued to raise the necessary capital for a project that contributes to a low-carbon, climate-resilient economy. While green bonds can be issued by governments, multinational banks or corporations, most to date have been issued as AAA-rated securities by the World Bank and other multilateral development banks, such as the European Investment Bank (EIB) and the Asian Development Bank (ADB). Green bonds have been designed to attract capital from institutional investors, or as a means for governments to direct funding to climate change mitigation. The current market size for all green bond issuance approximately USD 15.6 billion - is still marginal (0.017\%) compared to the capital held in global bonds markets.

Green bonds are most promising when cities and national governments co-operate. Cities generally have lower credit ratings than their respective national governments, as their default risk is considered to be higher (Canuto and Liu, 2010). When cities and local governments issue green bonds, investors look for risk compensation. For this reason, the US federal government financially supports municipal bonds (through tax exemptions and subsidies). Some form of urban-national co-operation is thus required in order for green bonds to be a viable option for cities. For cities in low and middle- 
income countries, the World Bank offers green bonds as part of project financing within a country's assistance portfolio; co-operation with national governments is therefore necessary.

Green infrastructure banks could help solve market failures and the challenge of limited market size. Development banks serve to unify finances and distribute it across countries through projects like waste infrastructure or water treatment. Development banks like the Green Investment Bank (GIB), set up by the UK, may offer financial benefits such as technical assistance or a lengthened loan repayment period. For this purpose, the UK Government unified local government spending into a lump sum of GBP 100 million to invest in smaller waste infrastructure projects (typically in the range of GBP 1525 million), on a fully commercial basis. The waste infrastructure projects will be transacted initially through specialised fund managers experienced in this sector, in order to ensure that government funds are deployed on equal terms with private capital. The bank manages the full procurement process of these types of loans and investments (e.g. Chicago Infrastructure Trust, set up in 2012 at the city level).

\section{Wider application of carbon finance}

Obstacles to cities' access to carbon finance need to be addressed. Cities could take better advantage of opportunities provided by carbon finance (Clapp et al., 2010). The two greenhouse gas offset mechanisms put in place by the Kyoto Protocol under the United Nations Framework Convention on Climate Change (UNFCCC) - the Clean Development Mechanism (CDM) and Joint Implementation (JI) - can serve as sources of revenue for metropolitan areas. CDM allows developed countries to purchase certified carbon credits from approved emission reduction projects in developing countries, and JI from emission reduction projects in other developed countries. In addition, voluntary carbon markets can and have been used to put a price on carbon, independent of any national emissions cap. Another option is to use domestic offsets as an incentive mechanism, by agreement between local and national governments; in this case national governments could agree to pay local governments for emission reductions achieved by local policies, thus assisting with the achievement of national mitigation targets. To date, the participation of cities and urban mitigation projects in the global carbon markets remains extremely limited for the following reasons (Clapp et al. 2010; World Bank, 2010):

- Limited autonomy of urban authorities to directly regulate greenhouse gas emissions;

- Limited budgets and access to start-up capital;

- Limited institutional and technical capacity;

- Difficulties in measuring the effects of urban mitigation projects with existing methodologies and lack of standardised methodologies (e.g. for greenhouse gas inventories at the urban level);

- Small scale of municipal-level greenhouse gas reduction initiatives (e.g. improving the efficiency of street lights) that do not warrant the transaction costs of pursuing carbon finance;

- Lack of support from national governments.

Overcoming these barriers could facilitate cities' engagement in carbon finance. Cities' future use of these instruments must be integrated into urban planning and financial frameworks so that carbon financing, if and when available to support urban mitigation projects, also contributes to the broader urban sustainability agenda. 


\section{ANNEX 1: THE PROMISES AND PITFALLS OF PUBLIC-PRIVATE PARTNERSHIPS}

While there are many definitions of PPPs, there are four commonly agreed features, which were clearly defined when the European Commission published the Green Paper on PPP in 2004 (OECD, 2008; FNEP and IGD, 2010):

a) A way to mobilise vast amounts of private investment while overcoming public authorities' inability to close massive and long-standing infrastructure deficits through public financing alone: PPPs are a "method of funding"/ funding tool for the project based partially or totally on private participation. The level of participation of private sector depends on the type of PPP arrangement;

b) The long duration of the relationship, involving co-operation between the public and private partners on different aspects of a project (to be implemented) or a service (to be managed): This co-operation is one key element since it leads to the "Partnership" nature in the publicprivate relationship;

c) The important role of the private operator, who participates at different stages in the project (design, completion, implementation and/or funding) depending on the PPP arrangement: Unlike traditional public sector procurement, where the private contractor simply designs and/or builds what the public sector orders, PPPs involve a competitive tendering process in which private operators bid for a contract to design, finance and manage the risks involved in delivering public services or assets. In return, the private contractor is paid fees by the public body and/or tolls from users for the long-term operation and maintenance of the asset;

d) The distribution of risks between the public partner and the private partner, according to the ability of concerned parties to assess, control and cope with this risk and the resulting economic optimum.

Since their development in the UK during the early 1990s, PFIs have been widely developed in many public services leading to important future obligation of payment from the government (Figure 10). Their development in other European countries is also significant. 
Figure 10. Estimated payments in real terms under signed PFI contracts in UK

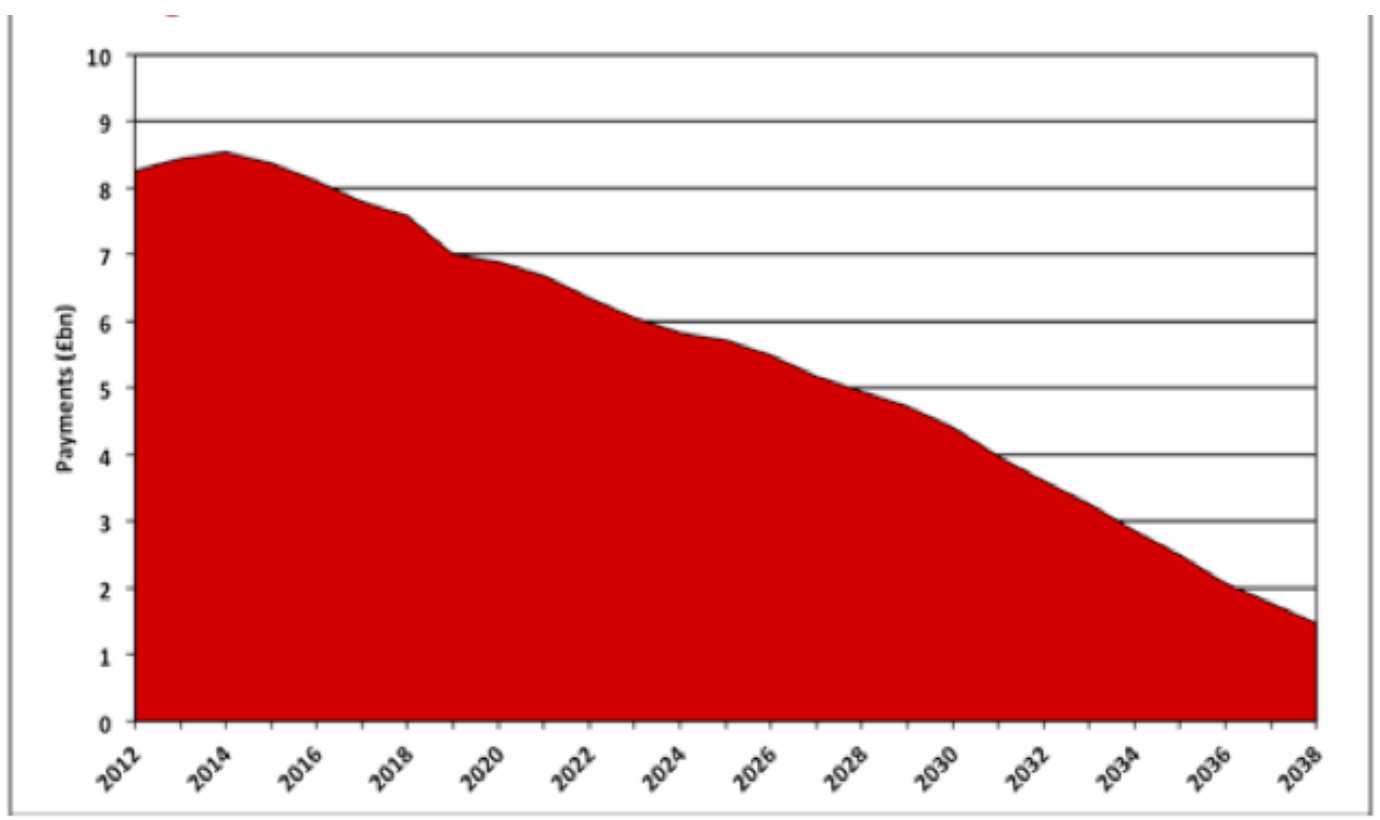

Source: HM Treasury (2011), “UK Private Finance Initiative Projects: Summary Data”, March, HM Treasury, London.

\section{PPPs potential advantages}

The PPP model has been widely adopted for public infrastructure projects in both developed and developing countries around the world (Estache, 2006). PPPs present numerous advantages on paper, but their effectiveness can only be assessed in comparison with other management methods. If public authorities do not want to go through PPPs, alternative options involve either in-house or traditional public procurement solutions to implement the necessary infrastructures to provide the service; the public service can then be operated through either direct public management (in-house) or a private contractor (supply contract). These are management methods that represent alternatives to PPPs and can be used as reference points to discuss their efficiency.

\section{Direct public management vs. PPPs}

The main consequence of direct public management is exclusion of the private operator. Comparing the effectiveness of direct public management to a private contractor is thus the same as comparing the advantages of the private sector or "the market solution" to the public solution (i.e. the externalisation vs. the in-house provision of a public service). There are two main arguments for justifying the use of private operators: the differential in skill and scale of operations, and market incentives.

a) Skills and economy of scale: Private companies that run PPP projects have experience. The skills they acquire over time permit them to offer better prices compared to a public entity with less experience. ${ }^{19}$ Moreover, the multiplicity of contracts awarded to private operators enables economies of scale: lower unit prices with increased production. Finally, some large companies are able to provide several services (roads and airports, water distribution and water treatment, water and transport, etc.), enabling economies of scope: substantial savings (reduced cost) when several products or services are provided together. 
b) Market incentives: Employee incentives for effectiveness are greater in PPPs than in an employment relationship that binds the government and a civil servant. Penalties for failing to respect the terms of the contract are higher in the market. The probability that the contract will not be renewed also generates incentives for the private operators to provide better services. ${ }^{20}$ Finding greater incentives is central to the decision to outsource a public service or any other activity (Williamson, 1985).

\section{Box 12. Arbitration between rents and incentives}

Suppose a company has an intrinsic productivity parameter $\beta$, which is characterised by operation costs $C$, such as: $C=\beta-e$. The level of cost $C$ is supposedly influenced not only by the intrinsic efficiency of the company, or $\beta$, its parameter of productivity (unobservable), but also by its level of effort $e$, which is costly for the company. This level of effort is chosen by the company and cannot be contractually imposed ( $e$ is a hidden unobservable action). To simplify, let's consider two types of companies operating on the market: efficient ones with a low productivity parameter $\beta_{\mathrm{L}}$ and inefficient ones with a high productivity parameter $\beta_{H}$. Let $\psi(e)$, an increasing and convex function in $e(i . e . \psi(e)>0$ and $\psi(e)>0$ ), which represents the cost of the productivity effort for the company. In this simple example, in order to obtain an adequate and efficient productivity level, we need $\psi(e)=1$ (i.e. the optimal level of effort chosen by the company must be such that the marginal cost of the effort equalises its marginal gain).

Such a result can be reached simply with a fixed price contract, for which the company is the residual claimant of his efforts (i.e. he retains the savings/ efficiency gains that are made). The problem is to set the price that remunerates the company at an adequate level. A price that is too high allows an effective company, with a low $\beta$, to maintain an informational income $\Delta \beta=\beta_{E}-\beta_{F}$. A price that is too low excludes inefficient companies and may even exclude efficient ones.

PPP contracts are typically price-capped, fixed-price contracts with strong incentives for administrators that incite them to reduce their costs and produce efficiently. By contracting on service obligations instead of obligations of means, these contracts provide strong incentives. However, it should be noted that these contracts are effective only to the extent that it is possible to contract on all the characteristics of the expected service. If not, private operators may be tempted to reduce their costs at the expense of the quality of service. Therefore, implementing a global contract (PPP) may incite them to use technology that will reduce operating costs; this will result in a mediocre quality of service if all the details regarding the quality expected for the public service in questions are not completely contractible. Hart et al.(1997) show that this type of strategy is being used in American prisons. The services delegated to the private sector are carried out by under-qualified prison guards, resulting in decreased operating costs as, well as reduced quality of service (i.e. prison violence, prison breaks, etc.) According to the authors, this is why the private sector runs prisons for minors, and not maximum security prisons housing dangerous offenders.

The traditional solution (i.e. traditional procurement) is similar to an "obligation of means" contract, which corresponds more to a cost-plus contract. In this case, costs are reimbursed: without incentives because productivity gains generated by the administrators are shared, but with the advantage of not inciting the reduction of operating costs and the expense of quality.

\section{Traditional public procurement vs. PPP}

Though the previous arguments can justify the use of the private sector, they cannot justify using PPPs over traditional public procurement. Authorities rely on private operators to build, maintain and provide public service for both PPPs and more traditional solutions, such as public procurement. Thus, the efficiency, or ineffectiveness, of PPPs cannot be based solely on the private firms' participation and their effectiveness compared to public bodies. Other arguments for the advantage of PPPs over traditional solutions focus on the advantages of a global contract and the governance mechanisms included in these contracts.

Setting up a global contract 
The main potential advantage of PPPs as stated in the economic literature is the ability to propose a global contract, linking several related phases of a project (e.g. design, investment, operation, infrastructure maintenance and the management of the corresponding public service). By proposing a global package to one private operator, the authorities give incentives to internalise reductions in operating costs, made possible through investment and proper design of infrastructure support (Hart, 2003; Bennett and Iossa, 2006; Martimort and Pouyet, 2008; Iossa and Martimort, 2008). This has serious implications for the level of incentives for private operators, as well as for the nature of the service provided.

This type of contract motivates the operator to take into account the complementarities between the various stages of the project. Signing a global contract changes the nature and intensity of the incentives received by the private operator, which results in changes to the amount of investments in place, to the revenues and/or general wellbeing generated by the service, and to the completion of the infrastructures. These benefits are rooted in the partnership created between the public and the private sectors, thus re-equilibrating the incentive abilities of the public and private parties and allowing private operators to consolidate various phases of a public project.

Deadlines for implementing a new infrastructure are met more readily with a PPP than with a traditional procedure. Several reports by the NAO show a positive effect on the completion of the project by the deadline for implementing infrastructure with PFI contracts that have been signed to date. A recent NAO study shows that "most private finance projects are built close to the agreed time, price and specifications: in our sample, $69 \%$ of PFI construction projects between 2003 and 2008 were delivered on time, and $65 \%$ were delivered at the contracted price. Of those delivered late, $42 \%$ were delivered within six months of the agreed time, and under half experienced price increases" (NAO, 2009). However, the favourable performance of PFIs in comparison with classic procurement, noted previously in English studies (HM Treasury, 2003), is reduced (see Table 5). In addition, the first empirical feedback also suggests that infrastructures are delivered within the allocated time, without delays that would reduce the social utility generated by the projects carried out as partnership contracts. Specifically, more than $95 \%$ of signed French PFIs in total or partial operation were completed on time (Nardi, 2010).

Table 5. The efficiency of English PFI vs. public sector

\begin{tabular}{|c|c|c|c|c|}
\hline \multirow[b]{2}{*}{ Project status } & \multicolumn{2}{|c|}{ H-M Treasury report } & \multicolumn{2}{|c|}{ NAO report } \\
\hline & PFI & Non-PFI & $P F I$ & Non-PFI \\
\hline On time & 88 & 30 & 69 & 65 \\
\hline On budget & 79 & 28 & 65 & 54 \\
\hline
\end{tabular}

Sources: H.M. Treasury (2003); NAO (2009).

This timeliness is explained in part by the strong incentives for the private operator. For example, payment does not begin before the operation phase of the service, and late penalties exist. Timeliness is also due to the private partner's increased participation and the unity of actions of this operator's actions (without involvement of a third party) at each phase of the project. Finally, when permitted by the type of contract and calls for tender, grouping the activities needed to carry out the project into one contract motivates the private operator to innovate to generate more revenue.

Private operators' signing on a global contract also affects investment levels for PPPs. In a recent study financed by the European Investment Bank, Blanc-Brude et al. (2009) investigated the 
construction costs of European motorway projects ( 227 projects, including 65 PPP projects) ${ }^{21}$ between 1990 and 2005. Construction costs were 25\% higher in PPP projects than the others. According to the authors, this excess might be explained by the will of the private operators to overinvest during the construction phase in order to reduce the operation costs that would follow and, ultimately, the overall project costs. The transfer of certain risks from the public sector to the private sector may also contribute to the cost differential. These potential advantages can only be obtained with the signing of a long-term contract, enabling a return on investments for the private operators.

In conclusion, economic literature states that the global nature of the PPP contract is essential to its efficiency. When all the phases are combined and carried out by one private operator, costs are minimised and the resulting value is maximised for the entire project. This results in investment strategies that differ from traditional procurement as long as it decreases operating costs and increases future revenue.

The primacy of the economic objectives

The economic literature also notes that PPPs are characterised by less political interference, thus allowing greater focus on economic objectives. PPPs are generally more supervised, with explicit or implicit preliminary evaluation procedures often lacking in public services under state control, or are limited to one phase of a project (as is the case for traditional procurement). Public bodies sometimes follow political rather than economic goals, which can affect the effectiveness of state-controlled services (Shleifer and Vishny, 1994). In contrast, when a private company is in charge of building an infrastructure or providing a service, it is faced with strong financial pressure, which limits the risk of political interference. In addition, PPPs require the government to clarify project objectives with a long-term vision. This clarification is beneficial because it obliges the public authorities to specify what is needed. This results in an analysis of the value of the program's elements, and often a decrease in demands. However, this work is not always clearly carried out through direct public management, resulting in the spiralling costs and delays often be seen in traditional projects or services.

Better expenditure planning and commitment

With a traditional solution, the government does not generally initiate long-term expenditure for infrastructure maintenance. With PPPs, however, the private operator must plan all the expenditures pertaining to the project. Thus, if traditionally managed work is hit by unexpected budget cuts, PPPs generally maintain a better residual value at the end of the project (Bennett and Iossa, 2006; Auriol and Picard, 2011).

\section{Potential pitfalls associated with PPPs}

While promises and positive feedbacks associated with PPPs exist, negative feedbacks also warn us that these promises are not automatic. PPPs might be suitable for some kind of transactions, and not for other. Therefore, a (theoretical) framework to highlight trade-offs is necessary.

\section{Transaction costs}

PPPs require the implementation of a long-term partnership that results in transaction costs - ex ante and ex post contracting costs (i.e. costs arising before and after the signature of the contract). These include costs for feasibility studies and diagnostics, choosing partners, writing the contract, enforcing the contract, and dealing with maladaptation and renegotiation (or amendments) to the contracts (Williamson, 1985). These costs need to be included in the calculus when assessing the costs and benefits to use PPPs compared to other solution. Some 
transaction costs also exist within the framework of in-house or traditional procurement solutions. However, due to the characteristics of PPPs (i.e. investments, long term contracts, incomplete contracts, uncertainty and risks), transaction costs are higher and harder to limit than with in-house and traditional procurement solutions. Because the contract relationship is generally shorter in traditional procurement, transaction costs for traditional solutions should take the form not of contracting costs, but of incentive decreases - a less visible drawback than the contracting problems generated by PPPs.

\section{Contract length and transaction costs}

Contract length is a crucial feature for PPP efficiency. A long-term contract can recoup the investment supported by a private operator that cannot be redeployed without costs. In theory, the contract length should be used not only to recoup the cost of an investment, but also to stagger all non-recurring expenses and to smooth out yearly hazards.

Pitfalls to long-term contracts do exist, however, and can suggest the benefits of a shorter-term contract - one that is shorter than amortisation period of the investments required by the private operator in charge of the service. Long-term contracts limit the frequency of calls for bids, thus reducing the competition level (i.e. with a long-term contract the private operator benefits from a monopoly for a longer period of time). If competition in the sector is already low, this should have a low impact. However, if the competitive intensity is high, missed opportunity to benefit from competition could be detrimental to the quality of the project.

\section{Incomplete contracting and transaction costs}

In addition, high level of uncertainty regarding important parameters of the contractual relationship, such as the obsolescence of the technologies used and the evolution of future demand, can be particularly problematic for long-term contracts. Uncertainty prevents contract completeness, induces mistakes and oversights, and thus necessitates frequent renegotiation of the original contract. Because these renegotiations can lead to high transaction costs, short-term contracting may sometimes be more effective for public authorities, even if the responses to calls for tenders are less advantageous or if service subsidies are necessary (Saussier, 2008).

Transaction costs emerge at different phases of the PPP's life cycle: the pre-contractual phase (feasibility study, selection and awarding process), the execution phase, and the postcontractual phase (renewal of the contract). In addition to the transaction costs that also exist in traditional procurement, there are transaction costs linked to the partnership aspects of public-private relationships. The informal features of these partnership relationships involving trust, reciprocity or reputation increase transaction costs. In order to generate mutual confidence, the involved stakeholders will have to make serious efforts towards cooperation and information sharing during the PPP's life cycle in order to facilitate the achievement of benefits associated with PPPs.

\section{Life cycle}

A complex PPP contract often requires a long and costly feasibility study and award-process phase. This pre-contractual phase (notably the selection and awarding process) is regulated but does leave some room in the process depending on the type of PPP. Difficulties related to the precontractual phase are generally due to the complex nature of the projects and the strategic behaviour of the actors who can impede the selection of the most efficient private operator with the most advantageous offer. These difficulties also have an impact on the execution phase of PPP contracts. 


\section{Project specification and competition}

The effectiveness of the call for bids depends primarily on the public authorities' ability to characterise the desired service. If the buyer cannot precisely outline the object of the call for tender, potential bidders may be discouraged from participating - due to costs of obtaining information needed to make an offer and fear of contract renegotiation, especially the risk of public authorities' attempt to make unilateral changes to the contract (Zupan, 1989a, 1989b; Spiller and Tommasi, 2003; Guasch and Straub, 2006). Fewer bidders hinder the anticipated benefits from competitive bidding.

\section{Project specification and aggressive offers}

If the service obligations are not properly specified, the tendering process may lead to the selection of the most opportunistic bidders (i.e. those most aware of holes in the contract that could be exploited ex post (Williamson, 1976; Bajari et al., 2009). An opportunistic candidate who hopes to take advantage of unforeseen situations in the contract because of its incompleteness will bid very low and, even as an inferior candidate, will thus be awarded the contract. The analysis proposed here by Guasch (2004) suggests that this is a frequent occurrence, especially in developing countries. In his analysis of over 1000 contracts in Latin American countries, Guasch shows that many contracts are renegotiated shortly after they have been signed (over $50 \%$ of the road concessions and over $70 \%$ of the water contracts are renegotiated within two years of their tendering), very often during the infrastructure building phase and to the advantage of the private administrators (i.e. with an increase in price and/or length of concession). The author concludes that offers by administrators do not constitute actual commitments.

Other studies from developed countries also show a high level of renegotiations for PPPs (Athias and Saussier, 2007). Nevertheless, observing a high level of renegotiations does not automatically mean the administrator or government representative is opportunistic. Any long-term contract must adapt to new conditions that cannot be anticipated when the contract is signed (Brux, 2010). In this sense, renegotiations are analysed as natural reformulations during the contract period.

\section{Uncertainty related to the project and optimistic offers}

Even if the government's expectations are clearly defined, each potential bidder may evaluate uncertainty associated with the project differently. This is more likely to occur when the private operator is paid from the revenue generated by the infrastructure being implemented, and there is real uncertainty regarding the future use of the work. The invitation to bid may results in the selection of candidates who are most optimistic regarding the future operating conditions and the future level of demand. This can lead to the so-called "winner's curse". ${ }^{22}$ This phenomenon, documented in a study by Athias and Nunez (2008), is more likely to occur when the institutional environment allows contracts to be easily renegotiated. Athias and Nunez's study examined 49 concession projects around the world and showed that private operators bid less aggressively when they expect strong competition (i.e. they include a risk premium based on the number of bidders in order to avoid the winner's curse). ${ }^{23}$ This behaviour is less evident in countries where the institutional framework is conducive to contract renegotiation.

\section{Enforcement costs}

Problems that arise during the execution phase of PPP contracts are linked to contract incompleteness, generating risks of opportunism by the partners (both government and private partner opportunism). Once the bid has been won and the contract begun, the partners may break their promises and attempt to renegotiate the initial contract. 
Unless there are serious and repeated counter-performances, the winner of a bid knows that there is little risk of being replaced before the end of the contract. Respect of the contract length is the return for the sustainable investments made; by guaranteeing length of commitments, the government can both incentivise actors to invest in long-term assets and prove its credibility to future partners. Rather than becoming involved in a lengthy and expensive process of conflict resolution, taking on the transition costs and facing a break in service, the unsatisfied buyer would prefer to continue the relationship and renegotiate a compromise (Williamson, 1976). Consequently, breaking the contract is very rare.

Moreover, because of their inherent incompleteness, contracts are not perfect ways to coordinate exchanges. They cannot foresee all of the future situations and must be adapted in case of disruption. Beneficially, this includes renegotiations to "realign" the contract with its economic environment (Brux, 2010). However, contract incompleteness also leaves room for strategic actions that result in costly renegotiations, unjustified from a social point of view; these renegotiations are generally bilateral and exclude important stakeholders - the consumers and citizens (Estache, 2006).

\section{Box 13. Frequency of renegotiations in concessions}

A study by Guasch (2004) is based on the analysis of over 1300 infrastructure concessions signed between 1980 and 2003 in Latin American and Caribbean countries. To our knowledge, this is the most exhaustive study (based on the largest number of concessions) that exists.

\begin{tabular}{|l|c|c|}
\hline Sector & \% of renegotiated contracts & $\begin{array}{l}\text { Average time before } \\
\text { renegotiation (in years) }\end{array}$ \\
\hline $\begin{array}{l}\text { All sectors } \\
\text { combined }\end{array}$ & $42 \%$ & 2.1 \\
\hline Electricity & $10 \%$ & 2.3 \\
\hline Transport & $57 \%$ & 3.1 \\
\hline Water & $75 \%$ & $\mathbf{1 . 7}$ \\
\hline
\end{tabular}

In addition to frequency, contract size was also analysed.

\begin{tabular}{|l|c|}
\hline & $\begin{array}{l}\% \text { of contracts negotiated } \\
\text { resulting in: }\end{array}$ \\
\hline Relaxation of the time frame & $69 \%$ \\
\hline Reduction of the time frame & $18 \%$ \\
\hline Increase of charges & $62 \%$ \\
\hline Reduction of charges & $19 \%$ \\
\hline $\begin{array}{l}\text { Increase in number of components with automatic } \\
\text { "pass-through" by increasing charges }\end{array}$ & $59 \%$ \\
\hline Extension of the concession period & $38 \%$ \\
\hline
\end{tabular}

Other less exhaustive studies show that renegotiations are just as common in industrialised countries. In a recent report, Engel et al. (2011) note that, in the case of transport concessions signed since 1991 in the United States, "six out of twenty projects have undergone a major change in the initial contractual agreement, favouring the concessionaire, and two additional projects have pending renegotiations" (Engel et al., 2011, 11). Regarding France, Athias and Saussier (2007) estimate that approximately $50 \%$ of the French motorway concession contracts underwent substantial renegotiations. A more recent study on parking concessions in France concludes that contracts are renegotiated about once every two and a half years (Brux et al., 2011). This study indicates that frequency of renegotiations does not seem to reflect disagreements between the parties since it does not affect the probability of the parties renewing the contracts once they have ended.

In conclusion, the economic analysis and empirical feedback suggests that grouping several steps of the same project into one long-term contract can lead to a more efficient production and better 
quality of service - i.e. signing a PPP is more advantageous than going through traditional procurement. The few examples that we have mentioned are promising. However, there are some examples of unsuccessful PPP with empirical feedback that is less positive. These examples suggest that the gains in effectiveness of PPP are only potential, and certain conditions must be fulfilled for this potential to be reached (Engel et al., 2010). Costs at each step of a PPP's implementation could reduce, and even nullify a PPP's advantages. Therefore, costs must be minimised to maintain the anticipated profits from the PPP. The characteristics of PPPs are at the sources of their potential benefits and drawbacks compared to traditional procurement and internal solutions (Table 6). 
Table 6. Strengths and pitfalls of PPPs

\begin{tabular}{|c|c|c|}
\hline $\begin{array}{l}\text { Main Features of } \\
\text { PPP }\end{array}$ & Potential Strengths of PPP & Potential Pitfalls of PPP \\
\hline Global contracts & $\begin{array}{l}\text { Minimisation of the global cost } \\
\text { of the project (Hart, 2003) } \\
\Rightarrow \text { Incentive to invest and } \\
\text { innovate } \\
\Rightarrow \text { Economies of scale and } \\
\text { scope } \\
\Rightarrow \text { Management of the whole } \\
\text { project }\end{array}$ & $\begin{array}{l}\text { The selected operator is not always the } \\
\text { best one for each step of the project } \\
\Rightarrow \text { Scale and scope economies reduced } \\
\text { Contractualisation issues } \\
\Rightarrow \text { Lower intensity of competition } \\
\Rightarrow \text { Contractual rigidities } \\
\Rightarrow \text { Need to contractualise on verifiable } \\
\text { objectives }\end{array}$ \\
\hline LT agreement & $\begin{array}{l}\text { Allow to recoup for the cost of investment } \\
\Rightarrow \text { Incentive to invest } \\
\Rightarrow \text { Incentive to offer a good bid } \\
\Rightarrow \text { Incentive to offer a bid that minimise } \\
\text { costs over the whole duration of the } \\
\text { contract } \\
\Rightarrow \text { Smooth out yearly hazards }\end{array}$ & $\begin{array}{l}\text { Reduction of competition (lower number } \\
\text { of call for tenders) } \\
\text { Higher uncertainty on technology, level } \\
\text { of demand } \\
\Rightarrow \text { Need for flexibility and adaptation }\end{array}$ \\
\hline Complex project & $\begin{array}{l}\text { Competitive dialogue when used } \\
\Rightarrow \text { Helps innovation to emerge } \\
\Rightarrow \text { Fosters the use of private expertise and } \\
\text { competencies }\end{array}$ & $\begin{array}{l}\text { Contractual incompleteness } \\
\Rightarrow \text { Room for opportunistic behaviours } \\
\Rightarrow \text { Winner's curse } \\
\Rightarrow \text { Future renegotiations }\end{array}$ \\
\hline $\begin{array}{l}\text { Risk transfer to } \\
\text { private operator }\end{array}$ & $\begin{array}{l}\text { Transferring risks to the party best placed to } \\
\text { manage them ensures best value for money. }\end{array}$ & Risk premium increases the cost of PPP \\
\hline Spread payment & $\begin{array}{l}\text { Payment of the up-front investments is } \\
\text { spread through time with payment schemes } \\
\text { based on } \\
\Rightarrow \text { The demand (i.e. tolls or shadow tolls) } \\
\Rightarrow \text { The availability (i.e. performance } \\
\text { indicators) }\end{array}$ & LT agreement \\
\hline
\end{tabular}




\section{BIBLIOGRAPHY}

Allen \& Overy LLP (2010), Global Guide to Public-Private Partnerships, Allen \& Overy, London.

Anderson, J. (1990), “Tax Increment Financing: Municipal Adoption and Growth", National Tax Journal, Vol. 43, No. 2, pp. 155-64.

Athias, L. and A. Nunez (2008), "Winner's Curse in Toll Road Concessions", Economics Letters, Vol. 101, No. 3, pp. 172-174.

Athias, L. and S. Saussier (2007), «Un Partenariat Public-Privé Rigide ou Flexible ? Théorie et Applications aux Concessions Routieres », Revue Economique, Vol. 58, No. 3, pp. 565-576.

Auriol, E. and P. Picard (2011), "A Theory of BOT Concession Contracts", Centre for Economic Policy Research (CEPR) Discussion Papers, No. 8323, CEPR, London.

Bajari, P., R. S. MacMillan and S. Tadelis (2009), "Auctions versus Negotiations in Procurement: An Empirical Analysis", The Journal of Law, Economics and Organization, Vol. 25, No. 2, pp. $372-$ 399.

Bajari, P. and S. Tadelis, (2001), "Incentives versus Transaction Costs: A Theory of Procurement Contracts", RAND Journal of Economics, Vol, 32, No. 3, pp. 387-407.

Baker, G., R. Gibbons and K. J. Murphy (2002), "Relational Contracts and the Theory of the Firm", The Quarterly Journal of Economics, Vol. 117, No. 1, pp. 39-84.

British Columbia Ministry of Community Services (2005), Development Cost Charge Best Practices Guide. British Columbia (BC) Ministry of Community Services, Victoria, BC.

Beevers, S. D. and D. C. Carslaw (2005), "The Impact of Congestion Charging on Vehicle Emissions in London”, Atmospheric Environment, Vol. 39, No. 1, January, pp. 1-5.

Bennett, J. and E. Iossa, (2006), "Building and Managing Facilities for Public Services", Journal of Public Economics, Vol. 90, No. 10-11, pp. 2143-2160.

Bird, R. M. and E. Slack (2004), International Handbook on Land and Property Taxation, Edward Elgar, Cheltenham, UK.

Bird, R. M. and E. Slack (2007), "Taxing Land and Property in Emerging Economies: Raising Revenue ... and More", in G. Ingram and Y-H Hong (eds.), Land Policies and Their Outcomes, Lincoln Institute of Land Policy, Cambridge, MA.

Bird, R. M., E. Slack and A. Tassonyi (2012), A Tale of Two Taxes: Property Tax Reform in Ontario, Lincoln Institute of Land Policy, Cambridge, MA.

Blais, P. (2010), Perverse Cities: Hidden Subsidies, Wonky Policy, and Urban Sprawl. UBC Press, Vancouver, BC. 
Blanc-Brude, F., H. Goldsmith and T. Valila (2009), "A Comparison of Construction Contract Prices for Traditionally Procured Roads and Public Private Partnerships", Review of Industrial Organization, Vol. 35, No. 1-2, pp. 19-40.

Bourassa, S. (1990), "Land Value Taxation and Housing Development: Effects of the Property Tax Reform in Three Types of Cities", American Journal of Economics and Sociology, Vol. 49, No. 1, pp. 101-111.

Briffault, R. (2010), “The Most Popular Tool: Tax Increment Financing and the Political Economy of Local Government", University of Chicago Law Review, Vol. 65.

Brueckner, J. K. (2001), "Property Taxation and Urban Sprawl”, in W. E. Oates (ed.), Property Taxation and Local Government Finance. Lincoln Institute of Land Policy, Cambridge, MA.

Brueckner, J. and H. A. Kim (2003), "Urban Sprawl and the Property Tax", International Tax and Public Finance, Vol. 10, No. 1, pp. 5-23.

Brux, J. de (2010), "The Dark and Bright Sides of Renegotiation: An Application to Transport Concession Contracts", Utilities Policy, Vol. 18, No. 2, pp. 77-85.

Brux, J. de, J. Beuve and S. Saussie (2011a), "Renegotiations and Contract Renewals in PPPs: An Empirical Analysis", Paper presented at Conference on Contracts, Procurement, and Public-Private Agreements, Paris, 30 May.

Brux, J. de, C. Desrieux and V. Piron (2011b), «Risques, Choix des Projets à Réaliser et Choix Contractuels », Transport, Vol. 465, pp. 1-11.

Buildings Performance Institute Europe (BPIE) (2010), Cost Optimality: Discussing Methodology and Challenges within the Recast Energy Performance of Buildings Directive, BPIE, www.buildup.eu/system/files/content/BPIE_costoptimality_publication2010.pdf.

Burge, G. S. (2010), "The Effects of Development Impact Fees on Local Fiscal Conditions", in G. K. Ingram and Y-H Hong (eds.), Municipal Revenues and Land Policies, Lincoln Institute of Land Policy, Cambridge, MA, pp. 182-212.

Canuto, O. and L. Liu (2010), "Sub-National Debt Finance: Make it Sustainable", World Bank Working Paper, World Bank, Washington DC.

Chernick, H., A. Langley and A. Reschovsky (2010), Revenue Diversification and the Financing of Large American Central Cities, Working Paper, Lincoln Insitute of Land Policy, Cambridge, MA.

Chong, E., F. Huet S. and Saussier (2006), "Auctions, Ex Post Competition and Prices: The Efficiency of Public-Private Partnership", Annals of Public and Cooperative Economics, Vol. 77, No. 4, pp. 517-549.

Clapp, C, A. Leseur, O. Sartor, G. Briner, J. Corfee-Morlot (2010), "Cities and Carbon Market Finance: Taking Stock of Cities' Experience with Clean Development Mechanism (CDM) and Joint Implementation (JI)”, OECD Environmental Working Paper No. 29, OECD, Paris. 
Corfee-Morlot, J., V. Marchal, C. Kauffmann, C. Kennedy, F. Stewart. C. Kaminker and G. Ang (2012), "Towards a Green Investment Policy Framework: The Case of Low-Carbon, ClimateResilient Infrastructure", OECD Environment Working Papers, OECD, Paris.

Dachis, D. (2011), "Congestive Traffic Failure: The Case for High-Occupancy and Express Toll Lanes in Canadian Cities", Essential Policy Intelligence E-brief, August, C. D. Howe Institute, www.cdhowe.org/pdf/ebrief_122.pdf.

Davies, P. and K. Eustice (2005). Delivering the PPP promises in Europe. PriceWaterhouseCoopers (PwC), www.pwc.com/en_GX/gx/government-infrastructure/pdf/promisereport.pdf.

Della Croce, R., C. Kaminker, F. Stewart (2011), The Role of Pension Funds in Financing Green Growth Initiatives, OECD Working Papers on Finance, Insurance and Private Pensions, No.10, OECD, Paris

Deskins, J. and W. Fox (2010), "Measuring the Behavioral Responses of the Property Tax", in R. Bahl, J. Martinez-Vazquez, and J. Youngman, Challenging the Conventional Wisdom of the Property Tax, Lincoln Instittue of Land Policy, Cambridge, MA, pp. 47-66.

Desrieux, C., E. Chong and S. Saussier (2008), "Horizontal Integration and Relational Contracting: An Application to the French Water Sector", Working Paper, http://pdfcast.org/pdf/horizontalintegration-and-relational-contracting-an-application-to-local-public-services.

Dye, R. and D. Merriman (2006), "Tax Increment Financing: A Tool for Economic Development”, Land Lines, Vol.18, No. 1.

Engel, E., R. Fischer and A. Galetovic (1997), "Highway Franchising: Pitfalls and Opportunities", The American Economic Review, Vol. 87, No. 2, pp. 68-72.

Engel, E., R. Fischer and A. Galetovic (2006), "Privatizing Highways in the United States", Review of Industrial Organization, Vol. 29, No. 1, pp. 27-53.

Engel, E., R. Fischer, and A. Galetovic (2010), “The Economics of Infrastructure Finance: PublicPrivate Partnerships versus Public Provision”, EIB Papers, No. 2/2010, European Investment Bank, Economics Department, Luxembourg.

Engel, E., R. Fisher and A. Galetovic (2011), "Public-Private Partnerships to Revamp U.S. Infrastructure", Discussion Paper 2011-02, The Hamilton Project, Brookings.

Estache, A. (2006), "PPI Partnerships vs. PPI Divorces in LDCs”, Review of Industrial Organization, Vol. 29, No. 1, pp. 3-26.

European Commission (2009), "Regulation (Ec) No. 714/2009 of the European Parliament and of the Council of 13 July 2009 on Conditions for Access to the Network for Cross-Border Exchanges in Electricity and Repealing Regulation (EC) No. 1228/2003”, Off. J. Eur. Union L 211, 15-35.

Fox, W. F. and E. Slack (2010), "North America", The State of Local Government Finance: Are We Ready to Face the Demand, United Cities and Local Governments, Barcelona, pp. 289-314. 
FNEP (Foundation Nationale Enterprise et Performance) and IGD (1'Institut de la Gestion Deleguee) (2010), "Partenariats Public-Privé et Performance des Investissements Publics", Public presentation of the work of Mission 2009, Science Po, Paris, 21 October.

Fróes, M. and J. Rebelo (2006), "Urban Operations and the São Paulo Metro Line 4", Working paper, World Bank, http://web.worldbank.org/WBSITE/EXTERNAL/TOPICS/EXTTRANSPORT/EXTURBANTRA NSPORT/0,,contentMDK:20249518 menuPK:610867 pagePK:148956 piPK:216618 theSitePK: 341449,00.html.

Gdesz, M. (2005), “Adjacency Levies in Poland - Main Problems”, paper for FIG Working Week 2005, 16-21 April 2005, Cairo.

George, H. (1879), Progress and Poverty: An Inquiry into the Cause of Industrial Depressions and of Increase of Want with Increase of Wealth: The Remedy, Doubleday, Page \& Co., Garden City, NY.

Gillingham, K., R. G. Newell and K. Palmer (2009), "Energy Efficiency Economics and Policy", Annual Review of Resource Economics, Annual Reviews, Vol. 1, No. 1, pp. 597-620.

Greater Toronto Area (GTA) Task Force (1996), Greater Toronto. GTA Task Force, Toronto.

Guasch, J. L. (2004), Granting and Renegotiating Infrastructure Concession: Doing It Right. World Bank, Washington DC.

Guasch, J. L. and S. Straub (2006), "Renegotiation of Infrastructure Concessions: An Overview", Annals of Public and Cooperative Economics, Vol. 77, No. 4, pp. 479-493.

Hart, O. (2003), "Incomplete Contracts and Public Ownership: Remarks, and an Application to PublicPrivate Partnerships", The Economic Journal, Vol. 113, No. 485, Conference Papers (March), Blackwell Publishing for the Royal Economic Society, pp. C69-C76.

Hart, O., A. Shleifer and R. W. Vishny (1997), "The Proper Scope of Government: Theory and an Application to Prisons, Quarterly Journal of Economics, Vol. 112, No. 4, pp. 1127-1161.

Haveman, M. and Sexton, T. A. (2008), Property Tax Assessment Limits: Lessons from Thirty Years of Experience, Lincoln Institute of Land Policy, Cambridge, MA.

House of Commons Committee of Public Accounts (2003), "Delivering Better Value for Money from the Private Finance Initiative", Twenty-eighth Report of Session 2002-03 (HC 764), House of Commons, London.

House of Commons Treasury Committee (2011), "Private Finance Initiative", Seventeenth report of Session 2010-2012 (HC1146), House of Commons, London.

Houser, T. (2009), The Economics of Energy Efficiency in Buildings, Peterson Institute for International Economics, http://www.piie.com/publications/pb/pb09-17.pdf.

HM Treasury (2003), PFI: Meeting the Investment Challenge, HM Treasury, London. 
HM Treasury (2011), "UK Private Finance Initiative Projects: Summary Data”, March, HM Treasury, London, www.hm-treasury.gov.uk/d/pfi_data_summary_november_2011.pdf.

Hong, H. and M. Shum (2002), "Increasing Competition and the Winner's Curse: Evidence from Procurement", Review of Economic Studies, Vol. 69, No. 4, pp. 871-898.

Hoornweg, D. et al. (eds.) (2011), Cities and Climate Change: Responding to an Urgent Agenda, World Bank, Washington DC.

IEA (2011), Energy for All: Financing Access for the Poor, World Energy Outlook 2011, International Energy Agency, Paris.

Iossa, E. and D. Martimort (2008), "The Simple Micro-Economics of Public-Private Partnerships", CEIS Working paper No. 139, CEIS, http://dx.doi.org/10.2139/ssrn.1271082.

Kamal-Chaoui, L. and A. Robert (2009), Competitive Cities and Climate Change, OECD, Paris.

Kaminker, C., F. Stewart (2012), "The Role of Institutional Investors in Financing Clean Energy", OECD Working Papers on Finance, Insurance and Private Pensions, No. 23, OECD Publishing

Katherine F. et al. (2009), "Saving Energy Cost Effectively: A National Review of the Cost of Energy Saved Through Utility-Sector Energy Efficiency Programs", Research Report U029, American Council for an Energy Efficient Economy (ACEEE), http://www.aceee.org/researchreport/u092.

Kennedy, C. et al. (2010), "Getting to Carbon Neutral: A Review of Best Practices in Infrastructure Strategy", in Bose, B. K. (ed), Energy Efficient Cities: Assessment Tools and Benchmarking Practices, World Bank, Washington DC, pp. 165-184.

KPMG (2011), CDP Cities 2011 Global Report on C40 Cities, Carbon Disclosure Project, c40citieslive.squarespace.com/storage/CDP\%20Cities\%202011\%20Global\%20Report.pdf.

Lambert-Mogiliansky, A. and G. Kosenok (2009), "Fine-Tailored for the Cartel-Favoritism in Procurement", Review of Industrial Organization, Vol. 35, No. 1-2, pp. 95-121.

LeRoy, G. (2008), "Greenfields, and Sprawl: How an Incentive Created to Alleviate Slums Has Come to Subsidize Upscale Mall and New Urbanist Developments", Planning and Environmental Law, Vol. 60, No. 2, pp. 3-11.

Managan, K. and P. Sweatman (2010), Financing Energy Efficiency Building Retrofits. Climate Strategy and Partners, www.climatestrategy.es/index.php?id=19\&accion=download\&item $=7$.

Marron, D. B. (1997), "Buying Green: Government Procurement as Instrument of Environmental Policy", Public Finance Review, Vol. 25, pp. 285-305.

Marshall, J. (2008), Fiscal Variables and Urban Sprawl, Ph.D. Thesis, University of Tennessee, Knoxville.

Martimort, D. and J. Pouyet (2008), "To Build or Not to Build: Normative and Positive Theories of Public-Private Partnerships”, International Journal of Industrial Organization, Vol. 26, No. 2, pp. 
393-411.

Maskin, E. and J. Tirole (2008), "Public-Private Partnerships and Government Spending Limits", International Journal of Industrial Organization, Vol. 26, No. 2, pp. 412-420.

Mathis, E. and C. Zech (1982), “An Empirical Test: The Economic Effects of Land Value Taxation”, Growth and Change, Vol. 13, No. 4, pp. 2-5.

Maurer, R. and A. Paugam (2000), Reform toward Ad Valorem Property Tax in Transition Economies: Fiscal and Land Use Benefits, World Bank, Washington, DC.

McAfee, R. P. and J. MacMillan (1987), "Auctions and Bidding”, Journal of Economic Literature, Vol. 25, No. 2, pp. 699-738.

McGuire, T. J., and D. L. Sjoquist (2003), "Urban Sprawl and the Finances of State and Local Governments", in D. Sjoquist (ed.), State and Local Finances Under Pressure, Elgar Publishing, Cheltenham, UK and Northampton, MA, pp. 29-326.

Morris, A. C. (1998), "Property Tax Treatment of Farmland: Does Tax Relief Delay Development?", in H. Ladd, Local Government and Land Use Policies in the United States, Edward Elgar, Cheltenham, pp. 144-67.

NAO (UK National Audit Office) (2004), London Underground PPP: Were they good deals?, NAO, London.

NAO (2009), "Private Finance Projects", A Paper for the Lords Economic Affairs Committee, October, NAO, London.

Nardi, T. (2010), «La Gestion du Temps en Contrat de Partenariat », Rapport Technique Rapport Mappp, Mission d'Appui aux Partenariats Public-Privé, Paris

Nelson, A. and M. Moody (2003), Paying for Prosperity: Impact Fees and Job Growth. Brookings Institution Center on Urban and Metropolitan Policy, Washington, DC.

Netzer, D. (1998), "The Relevance and Feasibility of Land Value Taxation in the Rich Countries”,,in D. Netzer, Land Value Taxation: Can It and Will It Work Today?, Lincoln Institute of Land Policy, Cambridge, MA, pp. 109-136.

Oates, W. E. and R. M. Schwab (1997), “The Impact of Urban Land Taxation: The Pittsburgh Experience", National Tax Journal, Vol. 50, No. 1, pp. 1-21.

OECD (2007), Infrastructure to 2030 (Vol.2), Mapping Policy for Electricity, Water and Transport, OECD, Paris.

OECD (2008), Les Partenariats Public-Privé : Partager les Risques et Optimiser les Ressources, OECD, Paris.

OECD (2009), OECD Territorial Reviews: Copenhagen, Denmark, OECD, Paris.

OECD (2010a), OECD Territorial Reviews: Toronto, Canada, OECD, Paris. 
OECD (2010b), Cities and Climate Change, OECD, Paris.

OECD (2010c), OECD Territorial Reviews: Guangdong, China, OECD, Paris.

OECD (2011), "Cities and Green Growth: A Conceptual Paper", Issues paper for the 13th Session of the Working Party on Territorial Development Policies in Urban Areas, OECD, May.

Parry, M. et al. (2009), Assessing the Costs of Adaptation to Climate Change: A Review of the UNFCCC and Other Recent Estimates, International Institute for Environment and Development (IIED) and Grantham Institute for Climate Change, London.

Peterson, G. (2006), "Land Leasing and Land Sale as an Infrastructure-Financing Option”, World Bank Policy Research Working Paper, No. 4043, Washington DC.

Peterson, G. (2009), Unlocking Land Values for Urban Infrastructure Finance, World Bank Publications, Washington DC.

Plassmann, F. and T. Tideman (2000), «A Markov Chain Monte Carlo Analysis of the Effect of TwoRate Property Taxes on Construction”, Journal of Urban Economics, Vol. 47, No. 2, pp. 216247.

Quigley, M. (2007), A Tale of Two Cities: Reinventing Tax Increment Financing, The Heartfelt Institute, Chicago.

Saussier, S. (1998), «Théorie des Coûts de Transaction et Durée des Contrats : Une Analyse Empirique », Economie et Prévision, Vol. 135, No. 4-5, pp. 137-147.

Saussier, S., C. Staropoli and A. Yvrande-Billon (2009), "Public Private Agreements, Institutions and Competition: When Economic Theory Meets Facts", Review of Industrial Organization, Vol. 35, No. 1, pp. 1-18.

Shleifer, A. and R. W. Vishny (1994), "Politicians and Firms", The Quarterly Journal of Economics, Vol. 109, No. 4, pp. 995-1025.

Skaburskis, A. (2003), "Planning City Form: Development Cost Charges and Simulated Markets", Planning Practice and Research, Vol. 18, No. 2, pp. 197-211.

Slack, E. (2002), Municipal Finance and the Pattern of Urban Growth, C. D. Howe Institute, Toronto.

Slack, E. and R. M. Bird (1991), "Financing Urban Growth Through Development Charges", Canadian Tax Journal, Vol. 39, No. 5.

Song, Y. and Y. Zenou (2009), "How Do Differences in Property Taxes Within Cities Affect Urban Sprawl?", Journal of Regional Studies, Vol. 49, No. 5, pp. 801-831.

Song, Y. and Y. Zenou (2006), "Property Tax and Urban Sprawl: Theory and Implications of US Cities", Journal of Urban Economics, Vol. 60, No. 3, pp. 519-34.

Spiller, P. T. (2008), “An Institutional Theory of Public Contracts: Regulatory Implications”, Working paper, National Bureau of Economic Research, Inc. 
Spiller, P. T. and M. Tommasi (2003), "The Institutional Foundations of Public Policy: A Transactions Approach with Application to Argentina", Journal of Law, Economics and Organization, Vol. 19, No. 2, pp. 281-306.

Stern, N. (2007), The Economics of Climate Change - The Stern Review, Cambridge University Press, January.

Talanker, A., K. Davis and G. LeRoy (2003), "How States are Weakening Enterprise Zone and Tax Increment Financing Programs", State Tax Notes, Vol. 3, No. 1, October.

Thompson, W. (1968), “The City as a Distorted Price System”, Psychology Today, Vol. 2, pp. 30-33.

Thomson, J. and T. Jackson (2007), "Sustainable Procurement in Practice: Lessons from Local Government", Journal of Environmental Planning and Management, Vol. 50, No. 3, pp. 421-444.

Tian, L. and W. Ma (2009), "Government Intervention in City Development in China: A Tool of Land Supply”, Land Use Policy, Vol. 26 (2009), pp. 599-609

Tomalty, R. and A. Skaburskis (1997), "Negotiating Development Charges in Ontario: Average Cost versus Marginal Cost Pricing of Services”, Urban Studies, Vol. 34, No. 12, pp. 1987-2003.

Tomalty, R. and A. Skaburskis (2003), "The Politics of Average versus Marginal Cost Pricing of Development Charges: A Canadian Case Study", in F. Ennis, Infrastructure Provision and the Negotiating Process, Ashgate, Hamshire, UK.

Torres, L. and V. Pina (2001), "Public Private Partnership and Private Finance Initiatives in the EU and Spanish Local Governments", The European Accounting Review, Vol. 10, No. 3, pp. 601619.

Wassmer, R. (1994), “Can Local Incentives Alter a Metro City's Economic Development?”, Urban Studies, Vol. 31, No. 8, pp. 1251-78.

WEF (2010), Green Investing 2010: Policy Mechanisms to Bridge the Financing Gap, World Economic Forum, Geneva.

Williamson, O. E. (1976), "Franchise Bidding for Natural Monopolies: In General and with Respect to CATV", Bell Journal of Economics, Vol. 7, No.1, pp.73-104.

Williamson, O. E. (1985), The Economic Institutions of Capitalism, The Free Press, New York.

Williamson, O. E. (1999), "Public and Private Bureaucracies: A Transaction Cost Economics Perspective", Journal of Law, Economics and Organization, Vol. 15, No. 1, pp. 306-342.

World Bank (2010), A City-Wide Approach to Carbon Finance, World Bank, Washington DC.

Youngman, J. (2011), TIF at a Turning Point: Defining Debt Down, Lincoln Institute of Land Policy, Cambridge, MA.

Zupan, M. A. (1989a), "Cable Franchise Renewals: Do Incumbent Firms Behave Opportunistically?", RAND Journal of Economics, Vol. 20, No. 4, pp. 473-482. 
Zupan, M. A. (1989b), "The Efficacy of Franchise Bidding Schemes in the Case of Cable Television: Some Systematic Evidence", Journal of Law and Economics, Vol. 32, No. 2, pp. 401-456. 


\section{NOTES}

1 These recommendations are the result of discussion and adoption at the OECD Roundtable of Mayors and Ministers, $8^{\text {th }}$ March 2012 in Chicago, Illinois, United States.

2 Effective property tax rates are calculated as total property tax revenues divided by the market value of properties.

This finding assumes that a change in the value of the property will be assessed for tax purposes on a regular basis. However, assessed values lag market values in many jurisdictions.

The choice of highest and best use (rather than current use) as the tax base is also likely to result in higher densities.

Levelised cost of energy (LCOE) is the USD/MWh (megawatt) price for an inflation-adjusted fixed-price off-take agreement that offers the project developer the minimum equity return necessary to undertake the project.

Article 2(1a) gives a purely qualitative definition: A "nearly zero-energy building" is a building that has a very high-energy performance. The nearly zero or very low amount of energy must come from renewable sources (to a very significant extent). The timescales are further amplified in Article 9 of the directive, which states that member states shall ensure that: (a) by 31 December 2020, all new buildings are nearly zero-energy buildings; and (b) after 31 December 2018, new buildings occupied and owned by public authorities are nearly zero-energy buildings.

Share of investment risks is the amount of operational revenue that guarantees the internal rate of return comparable to the government bond's rate of return on the private sector's capital.

The capital region includes the city of Seoul and Kyonggi province.

Brownfields are urban sites that are underutilised, often vacant, and sometimes contaminated. Because of their proximity to downtown areas where infrastructure is generally in place, brownfields hold a great deal of potential for redevelopment. The realisation of this potential is hindered, however, by cleanup costs of contaminated lands, the costs of upgrading or replacing existing but older infrastructure, and the liability. In many cases, traditional sources of private financing are hesitant to invest in brownfield sites because of the risks associated with their redevelopment. Although there is the potential for future rewards, these lands often remain unused because of a lack of upfront redevelopment financing. 
TIF legislation was passed by the provincial government in 2006, but the regulations have yet to be promulgated.

Earlier studies of TIFs that expand on their benefits include, for example, Wassmer (1994) and Anderson (1990). More recent studies question the use of TIFs. See, for example, Youngman (2011) and Briffault (2010).

In some US states, the TIF can also apply to the local portion of the sales tax.

A recent study suggests that legislative changes in 16 states have weakened TIFs by permitting them to be used in non-blighted areas; seven states strengthened their TIF programs (Talanker, Davis and LeRoy, 2003).

In Canada, development charges are also referred to as development cost charges and lot levies. In the US, impact fees are also called development fees, capacity fees, facility fees, capital recovery fees, system development charges, expansion fees, and mitigation fees (Burge, 2010).

Other exactions (formal or informal) on the developer are part of the subdivision approval process but are not strictly development charges. These include, for example, land dedications that require the developer to set aside land for roadways, other public works or school sites, or for environmental needs; parkland dedications that require a portion of the land used for development to be set aside for parkland (or a cash payment in lieu of parkland); density bonuses granted to developers (i.e. higher densities than permitted in the Official Plan, in return for meeting conditions such as providing day care or preserving a historic building); connection fees to permit developers to buy into existing capacity of water and sewer facilities; and over-sizing provisions (sometimes called front-end financing) that require developers to provide more infrastructure than is required for their development. The municipality, in some cases, agrees to recover part of the costs on behalf of the developer from future benefitting owners.

Municipalities in $\mathrm{BC}$ can only levy development cost charges for roads, drainage, sewers, water and parkland. The City of Vancouver, under its own legislation, can also levy for affordable housing and day care facilities.

According to a spokesperson of the World Bank Capital Markets Department.

For example, it is rare for a municipality to have several different management experiences for water services during one mandate, and therefore to be able to learn from the successes and failures of these experiences.

Even if contract renewal is not in the near future, the reputation of the contractor will have a significant effect on other potential contracts (Chong et al., 2006).

The 65 projects are concession contracts and PFIs.

The most optimistic respondents, if selected, are also those with the highest risk of going bankrupt during the contract - thus the winner's curse, which falls on the one who is chosen in this type of risky project.

This result is also found in the study by Hong and Shum (2002). 